\title{
Impact of Agronomic Biofortification with Zinc on the Nutrient Content, Bioactive Compounds, and Antioxidant Capacity of Cowpea Bean (Vigna unguiculata L. Walpers)
}

\author{
David López-Morales ${ }^{1}$, Efraín de la Cruz-Lázaro ${ }^{1, *(1)}$, Esteban Sánchez-Chávez ${ }^{2}$, \\ Pablo Preciado-Rangel ${ }^{3}\left(\mathbb{D}\right.$, César Márquez-Quiroz ${ }^{1}(\mathbb{D})$ and Rodolfo Osorio-Osorio ${ }^{1}$ \\ 1 División Académica de Ciencias Agropecuarias, Universidad Juárez Autónoma de Tabasco, Km. 25, \\ Carretera Villahermosa-Teapa, Ra. La Huasteca, 2da. Sección. Centro, Tabasco 86280, Mexico; \\ lopezmoralesd30@gmail.com (D.L.-M.); cesar.marquez@ujat.mx (C.M.-Q.); rodolfo.osorio@ujat.mx (R.O.-O.) \\ 2 Centro de Investigación en Alimentación y Desarrollo, A.C. Avenida Cuarta Sur No. 3820, \\ Fraccionamiento Vencedores del Desierto, Delicias, Chihuahua 33089, Mexico; esteban@ujat.mx \\ 3 Tecnológico Nacional de México, Instituto Tecnológico de Torreón, Torreón, Coahuila 27170, Mexico; \\ ppreciador@yahoo.com.mx \\ * Correspondence: efrain.delacruz@ujat.mx; Tel.: +52-993-358-1585
}

Received: 15 August 2020; Accepted: 22 September 2020; Published: 24 September 2020

\begin{abstract}
Zinc intake deficiency is a public health problem and increasing the nutrient's content in the edible parts of plants can help mitigate it. The objective of this work was to determine the effect of the edaphic and foliar application of zinc sulphate on the nutrient content, bioactive compounds, and antioxidant capacity of cowpea beans (Vigna unguiculata L. Walpers). A sample of 100 grains was taken, and the length, width, thickness, weight, ash content, fat, humidity, fibers, carbohydrates, protein, energy, macro- and micro- nutrients, total phenols, flavonoids, anthocyanins, and antioxidant capacity were determined. The $0.250 \mathrm{~g}$ edaphic- $12.5 \mathrm{mM}$ foliar dose produced grains of a greater weight and size. All of the edaphic and foliar doses increased the grain zinc content, and the highest value was found with the $0.125 \mathrm{~g}$ edaphic- $50.0 \mathrm{mM}$ foliar dose. The total phenols increased with $12.5 \mathrm{~g}$ of edaphic zinc, while phenols, flavonoids, and the antioxidant capacity increased with $50.0 \mathrm{mM}$ foliar zinc. The edaphic and foliar application of zinc sulphate increased the grain weight and size, zinc content, total phenols, and antioxidant capacity. Therefore, edaphic and foliar zinc biofortification enriches this nutrient in cowpea grains, and could reduce micronutrient malnutrition in the urban and rural communities of Mexico.
\end{abstract}

Keywords: biofortification; zinc sulphate; antioxidants; total phenols

\section{Introduction}

Pulses are the primary group of food legumes consumed in developing countries, and the second most important group of plants as a source of carbohydrates, proteins, amino acids, fibers, vitamins and phytochemicals [1]. Cowpea bean (Vigna unguiculata L. Walpers) is a legume and belongs to the family Fabaceae, tribe Phaseolae, genus Vigna, and section Catiang. It is a herbaceous annual crop, mostly grown in the dry agroecologies of the tropics in Latin America, Africa, and South Asia [2]. It is characterized by having significant contents of proteins, carbohydrates, fibers, vitamins, and nutrients, with a low-fat content and bioactive compounds, such as phenols and polyamines [3].These characteristics make cowpea potentially important to the human diet from a nutritional perspective. The content of zinc in the grains is often suboptimal, especially when produced in soils deficient in microelements [4]. 
Zinc is an essential micronutrient required in small quantities by all organisms [5]. The average total zinc concentration in cultivated soils is around $65 \mathrm{mg} \mathrm{kg}^{-1}$ and is predominantly taken up as a divalent cation $\left(\mathrm{Zn}^{2+}\right)$ [4] or bound to an organic acid [6]. As for micronutrients, zinc is an element whose deficiency symptoms are frequently observed in crops grown in tropical soils [7]. In plants, zinc is involved in correct membrane function, photosynthesis, gene expression, and protection against drought and pathogens, as well as in the synthesis of hormones that are involved in plant growth and development [6].

The inadequate dietary intake of this micronutrient constitutes a public health problem [8], which affects $17.3 \%$ of the world population, making it the fifth leading health risk factor in developing countries and the eleventh worldwide [9]. As a micronutrient, it is required in approximately $10 \%$ of human proteins for maintaining their catalytic activity [10], and acts by preventing lipid peroxidation [11], and in plants, it acts as a cofactor of approximately 300 enzymes, besides taking part in metabolism, fertility, seed production, chlorophyll formation, and defense against diseases [12,13]. There is also growing interest in how the micronutrient content of foods might be modified to benefit human health and nutrition.

To improve a crop's nutritional value, strategies such as agronomic biofortification have been applied. This is a technique that aims to improve the agronomic characteristics and increase the content of essential elements in the edible parts of plants, by applying these elements in edaphic and/or foliar doses [14,15]. Although the use of externally added micronutrients in the form of fertilizers can be effective, the relative efficiency of biofortification can vary from one plant species to another [6]. In this regard, some reports indicate that the combined application of edaphic and foliar zinc fertilizers can increase the grain zinc concentration, while simultaneously improving crop yields $[10,16]$. For example, biofortification with this micronutrient increases its grain content in Phaseolus vulgaris by $74.6 \%$ and the antioxidant capacity by $60 \%$, besides reducing its antinutrient content [10]. Increases in the zinc contents of the edible parts of Solanum tuberosum L. [17], Oryza sativa L. [18], Triticum aestivum L. [19], Zea mays L. [20], Allium cepa L. [21], and Carthamus tinctorius L. [22] have also been reported. In addition, a good response of cowpea to zinc fertilization has been reported in Mexico [5], Brazil [7], and Southern Africa [23]. In general, there are few reports on legume biofortification for the Vigna genus, and the results obtained from other works mainly focus on producing biofortified cereals. Therefore, the objective of the present work was to determine the effect of edaphic and foliar biofortification with zinc on the nutrients content, physicochemical properties, bioactive compounds, and antioxidant capacity of cowpea bean grains.

\section{Materials and Methods}

\subsection{Area of Study}

The experiment was carried out in the 2 nd Section of the "Ranchería Chipilinar", located in the municipality of Jalapa, Tabasco, Mexico, at $17^{\circ} 47^{\prime} 614^{\prime \prime} \mathrm{LN}$ and $92^{\circ} 47^{\prime} 764^{\prime \prime} \mathrm{LW}$, which has a warm humid climate $\operatorname{Af}(\mathrm{m}) \mathrm{w}^{\prime \prime}(\mathrm{i}) \mathrm{g}$. During the crop cycle, there were average maximum and minimum temperatures of 39 and $19{ }^{\circ} \mathrm{C}$, respectively, with a total precipitation of $185 \mathrm{~mm}$ (Figure 1). 


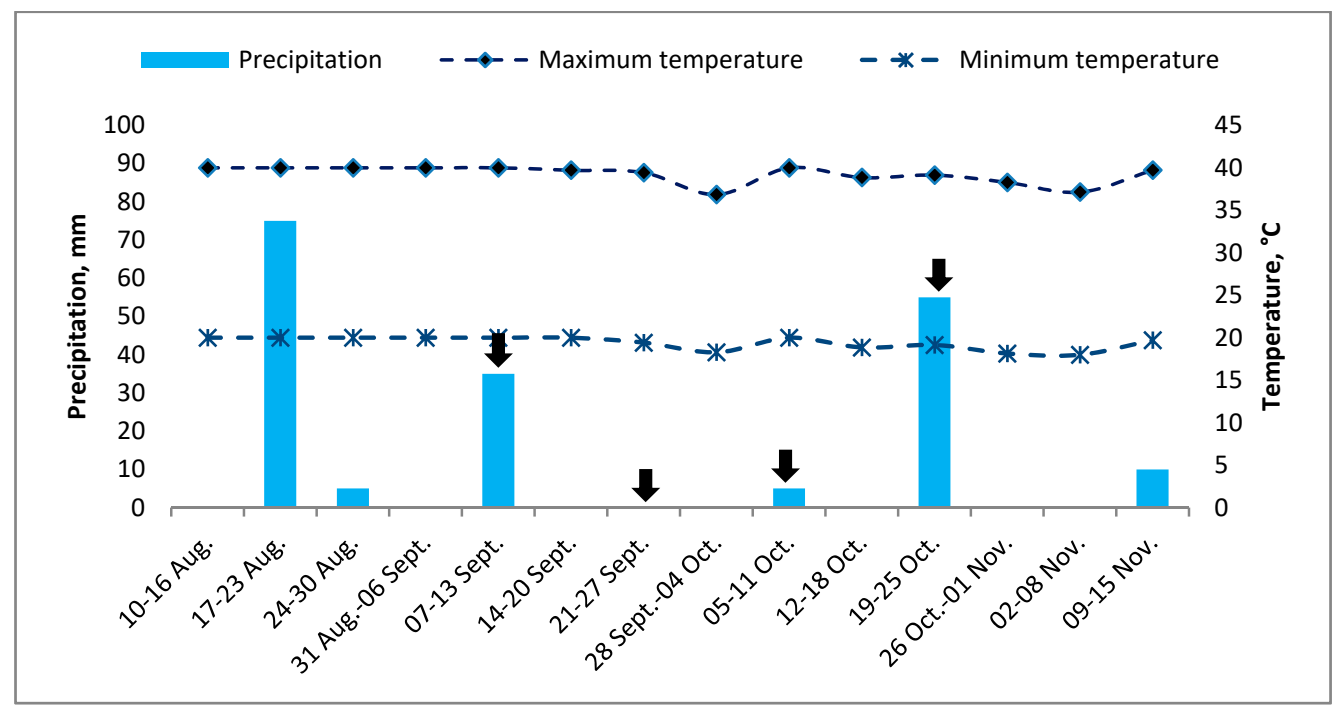

Figure 1. Precipitation and temperature weekly values during the cowpea bean (Vigna unguiculata L. Walpers) cultivation cycle. Arrows indicate zinc application dates.

\subsection{Soil Analysis}

A soil analysis of the experimental site was carried out before establishing the culture to determine the physicochemical characteristics by standard methodologies [24]. For this, a composite soil sample was collected by the "Zig-Zag" method with a $30 \mathrm{~cm}$ long Dutch-type auger. Table 1 presents the physicochemical properties of the experimental site's soil, which was slightly acidic and clayey, with moderately high organic matter (OM). Phosphorus and potassium contents were low, and the contents of iron $(\mathrm{Fe})$, manganese $(\mathrm{Mn})$, and copper $(\mathrm{Cu})$ were adequate, while zinc was minimal. Therefore, the soil was deficient in this mineral.

Table 1. Physicochemical properties of the soil $(0-30 \mathrm{~cm})$ at the cowpea bean (Vigna unguiculata L. Walpers) planting experimental site.

\begin{tabular}{cc}
\hline Physicochemical Properties & Results \\
\hline Textural class (Bouyoucos) & Clay soils \\
Apparent density (cylinder, $\mathrm{g} / \mathrm{cm}^{3}$ ) & 1.35 \\
pH (soil:water, 1:2) & 5.18 \\
EC $\left(\mu \mathrm{S} \mathrm{cm} \mathrm{cm}^{-1}\right.$ ) & 36 \\
OM (Walkley and Black, \%) & 3.81 \\
Nitrogen (micro-Kjeldahl, \%) & 0.18 \\
Phosphorus (P-Olsen, ppm) & 3.2 \\
Potassium (ammonium acetate, $\mathrm{cmol}^{+} \mathrm{kg}^{-1}$ ) & 0.17 \\
Calcium (ammonium acetate, $\mathrm{cmol}^{+} \mathrm{kg}^{-1}$ ) & 3.17 \\
Magnesium (ammonium acetate, $\mathrm{cmol}^{+} \mathrm{kg}^{-1}$ ) & 1.56 \\
Sodium (ammonium acetate, $\mathrm{cmol}^{+} \mathrm{kg}^{-1}$ ) & 0.26 \\
Iron (DTPA, ppm) & 73.6 \\
Zinc (DTPA, ppm) & 0.70 \\
Manganese (DTPA, ppm) & 35.0 \\
Cooper (DTPA, ppm) & 4.3 \\
\hline
\end{tabular}

\subsection{Crop}

A local cowpea (Vigna unguiculata L. Walpers) seed variety was used, which is planted by producers in the region (Figure 2). It is an important but under-studied grain legume which can potentially contribute to improving the dietary zinc intake. It has a short cycle, with an indeterminate growth habit, brown eye color, and beige grain color [25]. 


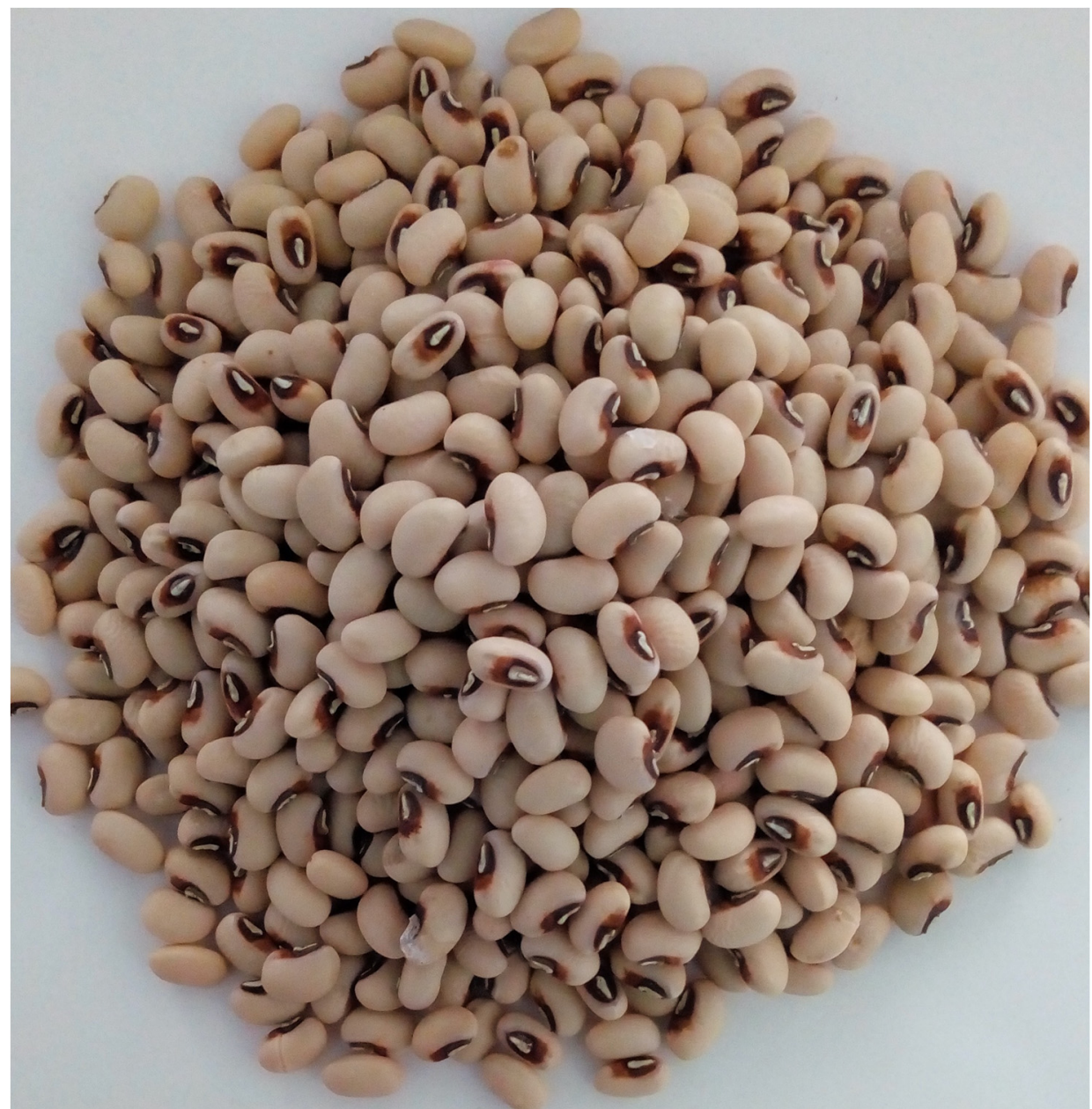

Figure 2. Seed sample of local cowpea (Vigna unguiculata L. Walpers) variety used.

\subsection{Treatments}

The experiment was started on 10 August 2018, under temporary conditions, by depositing four seeds per planting point, and then two plants per blow. Cowpea seeds were hand-sewn in rows with a spacing of $1 \mathrm{~m}$ between rows and $0.8 \mathrm{~m}$ between plants; the plot was $12 \mathrm{~m}^{2}$. Plants were set in a randomized complete block experimental design with four replicates. The treatments were distributed in a factorial design with four edaphic doses of $0.0,0.125,0.250$, and $0.500 \mathrm{~g}$ per plant and four foliar doses of $0.0,12.5,25.0$, and $50.0 \mathrm{mM} \mathrm{L}^{-1}$ of zinc sulphate (Maximo 362, Zinc Nacional S. A), which generated 16 treatments that were applied at 30,45, 60, and 75 days after planting (before flowering, flowering, early grain filling, and late grain filling stage). The edaphic doses were deposited at a depth of $5 \mathrm{~cm}$ and $5 \mathrm{~cm}$ from the plant. Meanwhile, the foliar doses were applied by spraying on the top and underside of the leaves until the dew point. The edaphic doses were applied from 04:00 to 06:00 p.m., and the foliar doses from 07:00 to 08:00 a.m.

\subsection{Harvest and Sample Preparation}

Grains were harvested manually at physiological maturity. From each treatment and repetition, 100 seeds were taken, which were ground in a mill. The sample resulting from the grinding was placed in aseptic bags and then used in the analysis of nutrient contents and bioactive compounds. 


\subsection{Analysis of Samples}

\subsubsection{Physical Properties of Cowpea Beans}

The axial dimensions of length, width, and thickness for 50 whole healthy grains were measured with an electronic Vernier caliper (STEREN). One hundred seeds from each treatment and replicate were weighed separately by using an analytical balance (HR-120), with an accuracy of $\pm 0.0001 \mathrm{~g}$. The weight was expressed in $\mathrm{g} 100^{-1}$ grains.

\subsubsection{Physicochemical Analysis}

Ash quantification was conducted under the Official Mexican Standard [26], in a melting pot at a constant weight, for which $1 \mathrm{~g}$ of each sample was weighed and placed in a muffle furnace at $600{ }^{\circ} \mathrm{C}$ for $24 \mathrm{~h}$, until calcination. Ash results were expressed as a percentage and were estimated as follows:

$$
\operatorname{Ash}(\%)=\frac{(P-p) \times 100}{M}
$$

where $P$ is the weight $(\mathrm{g})$ of the melting pot with the ashes, $p$ is the weight $(\mathrm{g})$ of the empty melting pot, and $M$ is the weight of the sample (g).

The fat content was determined with the Goldfish method proposed in the Official Mexican Standard [27]. Goldfish flasks were prepared and dried in a stove until reaching a constant weight. The Goldfish LABCONCO grease extractor kit (Labconco, Kansas City, MO, USA) was installed, and the sample was then placed inside filter paper, covered with cotton, and introduced into the kit. Petroleum ether was added as a solvent, leaving it at reflux for $2 \mathrm{~h}$ and $30 \mathrm{~min}$. After extraction, the solvent was recovered by distillation, retaining only the fat in the flask, which was weighed to express the fat content in percentage.

The crude fiber content was determined according to the Official Mexican Norm [28] using a degreased sample, which was transferred to fiberglass papers. Then, $200 \mathrm{~mL}$ of $1.25 \%$ sulfuric acid $\left(\mathrm{H}_{2} \mathrm{SO}_{4}\right)$ and $1 \mathrm{~mL}$ of isoamyl alcohol as antifoam were added, allowing the mixture to boil for $30 \mathrm{~min}$. Next, the samples were washed to remove the $\mathrm{H}_{2} \mathrm{SO}_{4}$ and isoamyl alcohol residues, as well as to neutralize the mixture. Subsequently, $200 \mathrm{~mL}$ of $1.25 \%$ sodium hydroxide $(\mathrm{NaOH})$ was added, and the sample was boiled for $30 \mathrm{~min}$. At the end of that time, the sample was washed in fiberglass until becoming neutral. Then, the fiberglass with the sample was placed in a capsule, put in an oven, and allowed to dry for $12 \mathrm{~h}$. Subsequently, the capsule with the fiberglass and the sample were weighed, and the percentage of fiber was determined by the weight difference.

Carbohydrates were determined by the difference from the other parameters and were expressed as a percentage with the following formula [29]:

$$
\% \text { carbohydrates }=100-(\text { ash }+ \text { protein }+ \text { fat }+ \text { moisture }+ \text { fiber }) .
$$

The protein content was determined with the Dumas method [30] by placing $3 \mu \mathrm{g}$ of each sample in nickel capsules, to which $9 \mu \mathrm{g}$ of vanadium pentoxide $\left(\mathrm{V}_{2} \mathrm{O}_{5}\right)$ was added and then introduced into the Flash 2000 kit (Thermo Scientific, Waltham, MA, USA). The protein concentration was expressed as a percentage $(\%)$.

The sum of calories in carbohydrates, fats, and proteins determined the energy of each sample, as described in the Official Mexican Standard [31]. The energy content was expressed in $\mathrm{kcal} \mathrm{kg}^{-1}$ and was estimated as follows:

$$
\text { Energy }=[(\text { fat } \times 9)+(\text { carbohydrates } \times 4)+(\text { protein } \times 4)]
$$




\subsubsection{Nutrient Content Analysis}

The micronutrient content was determined by triacid digestion. One gram of each sample was weighed on an analytical balance (HR-120), with an accuracy of $\pm 0.0001 \mathrm{~g}$. The sample was then placed in a $250 \mathrm{~mL}$ beaker with boiling beads, and $25 \mathrm{~mL}$ of triazide mixture $\left(1 \mathrm{~L}\right.$ of $\mathrm{HNO}_{3}$ concentrated, $100 \mathrm{~mL}$ of concentrated $\mathrm{HCl}, 25 \mathrm{~mL}$ of concentrated $\mathrm{H}_{2} \mathrm{SO}_{4}$ ) was added. Following this, the sample was placed in a digester grill in a fume hood for one hour. At the end, the resulting samples were filtered into $50 \mathrm{~mL}$ volumetric flasks (stock solution), gauged, and stirred with triple distilled water. Finally, samples were poured into $50 \mathrm{~mL}$ tubes in order to centrifuge them. The concentrations of $\mathrm{Mn}$, $\mathrm{Cu}, \mathrm{Fe}, \mathrm{Zn}$, and Ni were determined by atomic absorption spectrophotometry (AAS, iCE 3000 Series, Thermo Scientific, Waltham, MA, USA), and the results were expressed in ppm.

Macronutrients $(\mathrm{K}, \mathrm{Ca}, \mathrm{Mg}$, and $\mathrm{Na}$ ) were determined by atomic absorption spectrophotometry (AAS, iCE 3000 Series, Thermo Scientific, Waltham, MA, USA), by reporting the concentration in percentage. Phosphorus $(\mathrm{P})$ was determined by the colorimetric method of ammonium metavanadate $\left(\mathrm{NH}_{4} \mathrm{VO}_{3}\right)$ in an absorption range of $430 \mathrm{~nm}$ against a $\mathrm{K}_{2} \mathrm{HPO}_{4}$ calibration curve. In total, $3.5 \mathrm{~mL}$ of distilled water, $500 \mu \mathrm{L}$ of the stock solution, and $1 \mathrm{~mL}$ of phosphorus reagent $(\mathrm{P})$ were added to test tubes. Each tube was shaken in a vortex and allowed to stand for one hour. At the end, the reading was performed on a visible light spectrophotometer (Spectrophotometer, Genesis 10s UV/Vis, Thermo Scientific, Waltham, MA, USA). The P concentration was expressed as a percentage.

\subsubsection{Antioxidant Capacity}

The antioxidant capacity was determined by the method proposed by Hsu et al. [32]. The extract was obtained by macerating $1 \mathrm{~g}$ of each sample in $5 \mathrm{~mL}$ of $80 \%$ methanol, and samples were then centrifuged at $6000 \mathrm{rpm}$ for $10 \mathrm{~min}$ at $4{ }^{\circ} \mathrm{C}$. Five hundred microliters of the enzyme extract were taken and mixed with $2.5 \mathrm{~mL}$ of freshly prepared $0.1 \mathrm{mM}$ 2,2-diphenyl-1-picrylhydrazyl (DPPH) solution. The mixture was incubated for $60 \mathrm{~min}$ in dark and cold conditions. An absorbance reading was performed at $517 \mathrm{~nm}$ in a visible light spectrophotometer (JENWAY $6405 \mathrm{UV} / \mathrm{Vis}$ ). The result was expressed as a percentage of inhibition with the following formula:

$$
\% \text { ability to quench DPPH radicals }=\left(1-\frac{A_{\text {sample }}-A_{\text {blank }}}{A_{\text {reference }}}\right) \times 100
$$

where $A_{\text {sample }}$ is the sample absorbance, $A_{\text {blank }}$ is the blank absorbance, and $A_{\text {reference }}$ is the absorbance of the reference containing the DPPH radical.

\subsubsection{Bioactive Compounds}

The total phenol content was determined by the Folin-Ciocalteu method by spectrophotometry, using a standard curve of caffeic acid (10-100 $\left.\mu \mathrm{g} \mathrm{mL}^{-1}\right)$ [33]. For extraction, $1 \mathrm{~g}$ of a sample from each treatment and replicate was macerated in $5 \mathrm{~mL}$ of $80 \%$ methanol. It was then spun at $6000 \mathrm{rpm}$ for $10 \mathrm{~min}$ at a temperature of $4{ }^{\circ} \mathrm{C}$. To quantify the total phenols, $750 \mu \mathrm{L}$ of $2 \% \mathrm{Na}_{2} \mathrm{CO}_{3}, 250 \mu \mathrm{L}$ of $50 \%$ Folin-Ciocalteu, $1.375 \mathrm{~mL}$ of distilled water, and $250 \mu \mathrm{L}$ of the enzyme extract were mixed in a test tube. After incubation at room temperature for $60 \mathrm{~min}$, the absorbance at $725 \mathrm{~nm}$ was measured on a visible light spectrophotometer (Genesis 10s UV/Vis, Thermo Scientific, Waltham, MA, USA). The total phenol results were expressed in $\mathrm{mg}$ of gallic acid $\mathrm{g}^{-1}$ of dry weight (PS) (mg GA g ${ }^{-1} \mathrm{PS}$ ).

The flavonoid content was determined by the method proposed by Zhishen et al. [34]. For extraction, $0.5 \mathrm{~g}$ of each sample was macerated in $5 \mathrm{~mL}$ of $80 \%$ methanol, and samples were spun at $6000 \mathrm{rpm}$ for $10 \mathrm{~min}$ at a temperature of $4{ }^{\circ} \mathrm{C}$. To quantify flavonoids, $250 \mu \mathrm{L}$ of the enzyme extract and $75 \mu \mathrm{L}$ of $5 \% \mathrm{NaNO}_{2}$ were added to a test tube, vortexed, and allowed to stand for $5 \mathrm{~min}$. After that time, $150 \mu \mathrm{L}$ of $10 \%$ ALCL, $500 \mu \mathrm{L}$ of $1 \mathrm{M} \mathrm{NaOH}$, and $2.025 \mathrm{~mL}$ of distilled water were added. The sample was again stirred in the vortex and the absorbance at $510 \mathrm{~nm}$ was read on a visible light 
spectrophotometer (Genesis 10s UV/Vis, Thermo Scientific, Waltham, MA, USA). The flavonoid results were expressed in the mg equivalent of catechin $\mathrm{g}^{-1} \mathrm{PS}$ ( $\left.\mathrm{mg} \mathrm{CE} \mathrm{g}^{-1} \mathrm{PS}\right)$.

The determination of the anthocyanin content was carried out by the differential $\mathrm{pH}$ method proposed by Wrolstad et al. [35]. For this, $0.5 \mathrm{~g}$ of a sample from each repetition was macerated with $5 \mathrm{~mL}$ of $80 \%$ methanol, and then centrifuged at $6000 \mathrm{rpm}$ for $10 \mathrm{~min}$ at $4{ }^{\circ} \mathrm{C}$. The reaction mixture was carried out in two phases. In the first phase, $0.5 \mathrm{~mL}$ of the enzyme extract was taken and $2 \mathrm{~mL}$ of potassium chloride at $\mathrm{pH} 1.0$ was added; it was vortexed and the absorbance at $460 \mathrm{~nm}$ was measured. In the second phase, $0.5 \mathrm{~mL}$ of the enzymatic extract was taken and $2 \mathrm{~mL}$ of sodium acetate at $\mathrm{pH} 4.5$ was added, and stirred in a vortex to measure the absorbance at $710 \mathrm{~nm}$. Absorbance was determined on a visible light spectrophotometer (Genesis 10s UV/Vis, Thermo Scientific, Waltham, MA, USA). The results were reported in $\mathrm{mg}_{\text {of cyanidin-3-glucoside }}{ }^{-1}$ of PS (mg C3 $\mathrm{G} \mathrm{g}^{-1} \mathrm{PS}$ ).

\subsection{Experimental Design and Statistical Analysis}

A randomized complete block design was used under a $4 \times 4$ factorial arrangement; the factors were the edaphic (0.0, 0.125, 0.250, and $\left.0.500 \mathrm{~g} \mathrm{plant}^{-1}\right)$ and foliar $\left(0.0,12.5,25.0\right.$, and $\left.50.0 \mathrm{mM} \mathrm{L}^{-1}\right)$ doses of zinc sulphate, obtaining 16 treatments with four replicates. An analysis of variance and the comparison of means with the Tukey test $(p \leq 0.05)$ were performed on the data of each evaluated variable. All analyses were performed with the SAS software (SAS Institute Inc., Cary, NC, USA).

\section{Results}

\subsection{Physical Characteristics of the Cowpea Bean Grain}

Table 2 shows the physical characteristics of zinc biofortified cowpea beans (Vigna unguiculata L. Walpers). The width, length, and thickness displayed no significant differences between the edaphic and foliar doses of zinc sulphate. The grain width ranged between 5.40 and $5.85 \mathrm{~mm}$, while the length ranged from 8.15 to $8.55 \mathrm{~mm}$ and the thickness from 4.32 to $4.55 \mathrm{~mm}$, with the 0.250 g edaphic- $12.5 \mathrm{mM}$ foliar dose of zinc sulphate presenting the greatest width, length, and grain thickness. Although no statistical differences were detected between the control $(0.0 \mathrm{~g}$ of edaphic- $0.0 \mathrm{mM}$ foliar) and the different doses of edaphic and foliar zinc sulfate, the dose with $0.250 \mathrm{~g}$ of edaphic-12.5 mM foliar zinc sulfate presented the highest values for the width, length, thickness, and weight of 100 grains. Regarding the edaphic and foliar doses separately, significant differences were observed $(p \leq 0.05)$. For the edaphic doses, differences were only observed in the length and grain width, with the largest dimensions and grain weights shown for the dose of $0.250 \mathrm{~g}$. For foliar doses, the only statistical differences $(p \leq 0.05)$ were found in the weight of 100 grains, but with the dose of $12.5 \mathrm{mM}$, the highest values were obtained.

\subsection{Physicochemical Composition}

For the physicochemical variables, significant differences $(p \leq 0.05)$ were observed between the different edaphic and foliar zinc doses (Table 3). The ash content ranged between 3.37 and $4.08 \%$, with the highest concentrations being obtained with $0.500 \mathrm{~g}$ edaphic- $12.5 \mathrm{mM}$ foliar doses, compared to the control $(0.0 \mathrm{~g}$ of edaphic- $0.0 \mathrm{mM}$ foliar), which had the lowest concentration (3.37\%). Regarding the fat content, the highest concentration was found in the 0.250 g edaphic- $12.5 \mathrm{mM}$ foliar dose, with a value of $2.72 \%$ compared to $1.31 \%$, and the lowest value was recorded with the 0.0 g edaphic $-25.0 \mathrm{mM}$ foliar dose. The moisture content ranged between 11.09 and $11.92 \%$, exhibiting no significant differences between the edaphic and foliar doses of zinc sulphate. The fiber content ranged between 2.79 and $4.21 \%$. The carbohydrate content was lower with the $0.250 \mathrm{~g}$ edaphic- $25.0 \mathrm{mM}$ foliar dose, with a value of $49.43 \%$, while the $0.250 \mathrm{~g}$ edaphic- $50.0 \mathrm{mM}$ foliar dose increased its content to $54.46 \%$. The protein content with the 0.250 g edaphic- $25.0 \mathrm{mM}$ foliar dose showed the highest value $(29.59 \%)$, while the 0.250 g edaphic-50.0 mM foliar dose showed the lowest concentration (25.27\%). The lowest value of 
energy content was found in the $0.0 \mathrm{~g}$ edaphic- $25.0 \mathrm{mM}$ foliar dose, with a value of $3304 \mathrm{kcal} \mathrm{kg}^{-1}$, while the $0.250 \mathrm{~g}$ edaphic- $12.5 \mathrm{mM}$ foliar dose had the highest energy concentration ( $\left.3389 \mathrm{kcal} \mathrm{kg}^{-1}\right)$.

Individual effects of the edaphic and foliar doses produced significant differences $(p \leq 0.05)$ between the different doses. For the ash content, significant differences $(p \leq 0.05)$ were observed by the edaphic doses of 0.250 and $0.500 \mathrm{~g}$; the highest concentrations of fat $(p \leq 0.05)$ were observed with the dose of $0.250 \mathrm{~g}$. The protein, fiber, and humidity exhibited no significant differences between the edaphic doses. The highest values of protein, moisture, and fat were found in the $0.250 \mathrm{~g}$ dose, with values of $27.12,11.76$, and $2.01 \%$, respectively. For the carbohydrates, significant differences $(p \leq 0.05)$ were observed between doses $(0.125,0.250$, and $0.50 \mathrm{~g})$ and the control $(0.0 \mathrm{~g})$. In terms of the energy, the highest values $(p \leq 0.05)$ were observed in the doses of 0.125 and $0.250 \mathrm{~g}$ of zinc sulphate. For foliar doses, the highest values of ash, fat, and energy were found with the doses (12.5, 25.0, and $50.0 \mathrm{mM})$ of zinc sulphate, and the values were significantly different $(p \leq 0.05)$ to those obtained with the control ( $0.0 \mathrm{mM}$ zinc sulphate). The moisture and fiber were not significantly different for the foliar doses. The highest carbohydrate was observed in the doses of 25.0 and $50.0 \mathrm{mM}$, with significantly different values in comparison to the doses of 0.0 and $12.5 \mathrm{mM}$ of zinc sulphate. The highest values of protein were observed in the doses of $25.0,12.5$, and $0.0 \mathrm{mM}$ of zinc sulphate; values which were significantly different $(p \leq 0.05)$ to those obtained with the $50.0 \mathrm{mM}$ dose of zinc sulphate. The highest values of ash, fiber, and carbohydrate were observed with the $50.0 \mathrm{mM}$ foliar dose of zinc sulphate.

Table 2. Physical characteristics of the cowpea bean (Vigna unguiculata L. Walpers) biofortified with different doses of zinc sulphate.

\begin{tabular}{|c|c|c|c|c|c|}
\hline \multicolumn{2}{|c|}{ Doses } & \multirow{2}{*}{$\begin{array}{c}\text { Width } \\
(\mathrm{mm})\end{array}$} & \multirow{2}{*}{$\begin{array}{l}\text { Length } \\
(\mathrm{mm})\end{array}$} & \multirow{2}{*}{$\begin{array}{c}\text { Thickness } \\
\text { (mm) }\end{array}$} & \multirow{2}{*}{$\begin{array}{c}\text { Weight of } 100 \text { Grains } \\
\text { (g) }\end{array}$} \\
\hline Edaphic (g) & Foliar (mM) & & & & \\
\hline 0 & 0 & $5.48^{\mathrm{a}}$ & $8.15^{a}$ & $4.40^{\mathrm{a}}$ & $14.37 \mathrm{ab}$ \\
\hline 0 & 12.5 & $5.65^{\mathrm{a}}$ & $8.22^{a}$ & $4.55^{\mathrm{a}}$ & $14.35^{\mathrm{ab}}$ \\
\hline 0 & 25 & $5.63^{\mathrm{a}}$ & $8.44^{\mathrm{a}}$ & $4.43^{\mathrm{a}}$ & $14.15^{\mathrm{ab}}$ \\
\hline 0 & 50 & $5.55^{\mathrm{a}}$ & $8.22^{a}$ & $4.41^{\mathrm{a}}$ & $13.70^{b}$ \\
\hline 0.125 & 0 & $5.71^{\mathrm{a}}$ & $8.32^{a}$ & $4.50^{\mathrm{a}}$ & $14.20^{\mathrm{ab}}$ \\
\hline 0.125 & 12.5 & $5.70^{\mathrm{a}}$ & $8.28^{a}$ & $4.48^{\mathrm{a}}$ & $14.21^{a b}$ \\
\hline 0.125 & 25 & $5.65^{\mathrm{a}}$ & $8.50^{\mathrm{a}}$ & $4.51^{\mathrm{a}}$ & $13.95^{\mathrm{ab}}$ \\
\hline 0.125 & 50 & $5.59^{\mathrm{a}}$ & $8.24^{\mathrm{a}}$ & $4.41^{\mathrm{a}}$ & $14.03^{\mathrm{ab}}$ \\
\hline 0.25 & 0 & $5.71^{\mathrm{a}}$ & $8.35^{\mathrm{a}}$ & $4.54^{\mathrm{a}}$ & $14.22^{\mathrm{ab}}$ \\
\hline 0.25 & 12.5 & $5.85^{\mathrm{a}}$ & $8.55^{\mathrm{a}}$ & $4.55^{\mathrm{a}}$ & $14.70^{\mathrm{a}}$ \\
\hline 0.25 & 25 & $5.73^{\mathrm{a}}$ & $8.52^{a}$ & $4.46^{\mathrm{a}}$ & $14.41^{\mathrm{ab}}$ \\
\hline 0.25 & 50 & $5.76^{\mathrm{a}}$ & $8.49^{a}$ & $4.45^{\mathrm{a}}$ & $14.05^{\mathrm{ab}}$ \\
\hline 0.5 & 0 & $5.73^{\mathrm{a}}$ & $8.36^{a}$ & $4.47^{\mathrm{a}}$ & $14.29 \mathrm{ab}$ \\
\hline 0.5 & 12.5 & $5.77^{\mathrm{a}}$ & $8.40^{\mathrm{a}}$ & $4.54^{\mathrm{a}}$ & $14.28^{a b}$ \\
\hline 0.5 & 25 & $5.75^{\mathrm{a}}$ & $8.33^{a}$ & $4.48^{\mathrm{a}}$ & $14.02^{\mathrm{ab}}$ \\
\hline 0.5 & 50 & $5.55^{\mathrm{a}}$ & $8.26^{\mathrm{a}}$ & $4.32^{\mathrm{a}}$ & $13.71^{b}$ \\
\hline \multicolumn{2}{|c|}{$p$ value } & 0.7653 & 0.8274 & 0.7923 & 0.005 \\
\hline \multirow{4}{*}{ Edaphic } & 0 & $5.58^{b}$ & $8.26^{b}$ & $4.45^{\mathrm{a}}$ & $14.14^{\mathrm{a}}$ \\
\hline & 0.125 & $5.66^{\mathrm{ab}}$ & $8.34^{\mathrm{ab}}$ & $4.47^{\mathrm{a}}$ & $14.10^{\mathrm{a}}$ \\
\hline & 0.25 & $5.76^{\mathrm{a}}$ & $8.48^{a}$ & $4.50^{\mathrm{a}}$ & $14.35^{\mathrm{a}}$ \\
\hline & 0.5 & $5.70^{\mathrm{ab}}$ & $8.34^{\mathrm{ab}}$ & $4.46^{\mathrm{a}}$ & $14.07^{\mathrm{a}}$ \\
\hline \multicolumn{2}{|c|}{$p$ value } & 0.0128 & 0.041 & 0.6163 & 0.1921 \\
\hline \multirow{5}{*}{ Foliar } & 0 & $5.66^{\mathrm{a}}$ & $8.30^{\mathrm{a}}$ & $4.48^{\mathrm{ab}}$ & $14.27^{\mathrm{a}}$ \\
\hline & 12.5 & $5.74^{\mathrm{a}}$ & $8.36^{a}$ & $4.53^{\mathrm{a}}$ & $14.39^{\mathrm{a}}$ \\
\hline & 25 & $5.69^{\mathrm{a}}$ & $8.45^{a}$ & $4.47^{\mathrm{ab}}$ & $14.13^{\mathrm{ab}}$ \\
\hline & 50 & $5.61^{\mathrm{a}}$ & $8.30^{a}$ & $4.40^{\mathrm{a}}$ & $13.87^{b}$ \\
\hline & $p$ value & 0.1326 & 0.207 & 0.037 & $<0.0001$ \\
\hline
\end{tabular}

Values with the same letter within each column are the same according to the Tukey $p \leq 0.05$. 
Table 3. Physicochemical composition in cowpea beans (Vigna unguiculata L. Walpers) biofortified with different doses of zinc sulphate.

\begin{tabular}{|c|c|c|c|c|c|c|c|c|}
\hline \multicolumn{2}{|c|}{ Doses } & \multirow{2}{*}{$\begin{array}{l}\text { Ash } \\
(\%)\end{array}$} & \multirow{2}{*}{$\begin{array}{l}\text { Fat } \\
(\%)\end{array}$} & \multirow{2}{*}{$\begin{array}{l}\text { Moisture } \\
(\%)\end{array}$} & \multirow{2}{*}{$\begin{array}{c}\text { Fiber } \\
(\%)\end{array}$} & \multirow{2}{*}{$\begin{array}{c}\text { Carbohydrate } \\
(\%)\end{array}$} & \multirow{2}{*}{$\begin{array}{l}\text { Protein } \\
(\%)\end{array}$} & \multirow{2}{*}{$\begin{array}{c}\text { Energy } \\
\left(\mathrm{kcal} \mathrm{kg}^{-1}\right)\end{array}$} \\
\hline Edaphic (g) & Foliar (mM) & & & & & & & \\
\hline 0 & 0 & $3.37^{b}$ & $1.46^{\mathrm{cd}}$ & $11.89^{\mathrm{a}}$ & $3.49^{a}$ & $53.91^{a b}$ & $25.88^{a b}$ & $3323^{\mathrm{de}}$ \\
\hline 0 & 12.5 & $3.40^{b}$ & $1.37^{\mathrm{cd}}$ & $11.76^{\mathrm{a}}$ & $3.82^{\mathrm{a}}$ & $53.72^{a b}$ & $25.93^{\mathrm{ab}}$ & $3309 \mathrm{e}$ \\
\hline 0 & 25 & $3.41^{b}$ & $1.31^{\mathrm{d}}$ & $11.91^{\mathrm{a}}$ & $3.72^{\mathrm{a}}$ & $53.05^{\mathrm{ab}}$ & $26.60^{a b}$ & $3304^{\mathrm{e}}$ \\
\hline 0 & 50 & $3.51^{b}$ & $1.63^{\mathrm{cd}}$ & $11.09^{a}$ & $4.21^{\mathrm{a}}$ & $53.60^{\mathrm{ab}}$ & $25.96^{\mathrm{ab}}$ & 3329 de \\
\hline 0.125 & 0 & $3.43^{b}$ & $1.95^{b c}$ & $11.68^{a}$ & $3.91^{\mathrm{a}}$ & $52.68^{b}$ & $26.35^{a b}$ & $3337^{\mathrm{cd}}$ \\
\hline 0.125 & 12.5 & $3.48^{b}$ & $1.40^{\mathrm{cd}}$ & $11.68^{a}$ & $2.98^{a}$ & $52.47^{b}$ & $27.99^{a b}$ & $3344^{b c}$ \\
\hline 0.125 & 25 & $3.49^{b}$ & $1.77^{\mathrm{cd}}$ & $11.68^{\mathrm{a}}$ & $3.03^{a}$ & $52.30^{\mathrm{ab}}$ & $27.73^{a b}$ & $3361^{a b}$ \\
\hline 0.125 & 50 & $3.50^{b}$ & $1.84^{b c}$ & $11.92^{\mathrm{a}}$ & $2.79^{a}$ & $53.96^{\mathrm{ab}}$ & $25.99^{a b}$ & $3364^{a b}$ \\
\hline 0.25 & 0 & $3.95^{\mathrm{a}}$ & $1.51^{\mathrm{cd}}$ & $11.75^{\mathrm{a}}$ & $3.05^{\mathrm{a}}$ & $52.44^{b}$ & $27.30^{\mathrm{ab}}$ & $3326^{\text {de }}$ \\
\hline 0.25 & 12.5 & $3.98^{\mathrm{a}}$ & $2.72^{\mathrm{a}}$ & $11.86^{\mathrm{a}}$ & $2.92^{\mathrm{a}}$ & $52.16^{b}$ & $26.31^{\mathrm{ab}}$ & $3389^{a}$ \\
\hline 0.25 & 25 & $3.99^{\mathrm{a}}$ & $2.30^{a b}$ & $11.68^{a}$ & $3.01^{\mathrm{a}}$ & $49.43^{c}$ & $29.59^{\mathrm{a}}$ & $3368^{a}$ \\
\hline 0.25 & 50 & $4.02^{\mathrm{a}}$ & $1.53^{\mathrm{cd}}$ & $11.77^{\mathrm{a}}$ & $2.95^{\mathrm{a}}$ & $54.46^{\mathrm{a}}$ & $25.27^{b}$ & 3327 de \\
\hline 0.5 & 0 & $4.03^{\mathrm{a}}$ & $1.40^{\mathrm{cd}}$ & $11.83^{\mathrm{a}}$ & $2.83^{\mathrm{a}}$ & $54.34^{\mathrm{a}}$ & $25.62^{b}$ & 3324 de \\
\hline 0.5 & 12.5 & $4.08^{a}$ & $1.82^{\mathrm{bcd}}$ & $11.75^{\mathrm{a}}$ & $3.14^{\mathrm{a}}$ & $53.08^{a b}$ & $26.13^{a b}$ & $3332^{\mathrm{cd}}$ \\
\hline 0.5 & 25 & $4.04^{\mathrm{a}}$ & $1.57^{\mathrm{cd}}$ & $11.84^{\mathrm{a}}$ & $3.12^{\mathrm{a}}$ & $53.15^{\mathrm{ab}}$ & $26.28^{a b}$ & 3319 de \\
\hline 0.5 & 50 & $4.01^{\mathrm{a}}$ & $1.70^{\mathrm{cd}}$ & $11.39^{\mathrm{a}}$ & $3.48^{\mathrm{a}}$ & $53.60^{a b}$ & $25.82^{b}$ & 3330 de \\
\hline \multicolumn{2}{|c|}{$p$ value } & 0.2954 & $<0.0001$ & 0.1502 & $<0.0001$ & $<0.0001$ & 0.0011 & $<0.0001$ \\
\hline \multirow{4}{*}{ Edaphic } & 0 & $3.42^{b}$ & $1.44^{\mathrm{c}}$ & $11.66^{\mathrm{a}}$ & $3.81^{\mathrm{a}}$ & $52.12^{b}$ & $26.09^{a}$ & $3316^{b}$ \\
\hline & 0.125 & $3.47^{b}$ & $1.74^{\mathrm{b}}$ & $11.74^{\mathrm{a}}$ & $3.18^{a}$ & $52.85^{a b}$ & $27.01^{\mathrm{a}}$ & $3351^{a}$ \\
\hline & 0.25 & $4.00^{\mathrm{a}}$ & $2.01^{\mathrm{a}}$ & $11.76^{\mathrm{a}}$ & $2.98^{\mathrm{a}}$ & $53.57^{\mathrm{a}}$ & $27.12^{\mathrm{a}}$ & $3351^{\mathrm{a}}$ \\
\hline & 0.5 & $4.03^{\mathrm{a}}$ & $1.62^{b c}$ & $11.70^{\mathrm{a}}$ & $3.14^{\mathrm{a}}$ & $53.54^{\mathrm{a}}$ & $25.96^{\mathrm{a}}$ & $3326^{b}$ \\
\hline \multicolumn{2}{|c|}{$p$ value } & $<0.0001$ & $<0.0001$ & 0.2143 & 0.1202 & $<.0001$ & 0.1011 & $<0.0001$ \\
\hline \multirow{4}{*}{ Foliar } & 0 & $3.68^{b}$ & $1.56^{b}$ & $11.79^{\mathrm{a}}$ & $3.32^{a}$ & $51.98^{c}$ & $26.29 \mathrm{ab}$ & $3327^{b}$ \\
\hline & 12.5 & $3.75^{\mathrm{a}}$ & $1.83^{\mathrm{a}}$ & $11.76^{\mathrm{a}}$ & $3.21^{\mathrm{a}}$ & $52.86^{b}$ & $26.59^{a b}$ & $3343^{a}$ \\
\hline & 25 & $3.73^{a b}$ & $1.74^{\mathrm{ab}}$ & $11.78^{\mathrm{a}}$ & $3.22^{\mathrm{a}}$ & $53.34^{\mathrm{ab}}$ & $27.55^{\mathrm{a}}$ & $3337^{a b}$ \\
\hline & 50 & $3.76^{\mathrm{a}}$ & $1.67^{\mathrm{ab}}$ & $11.54^{\mathrm{a}}$ & $3.36^{\mathrm{a}}$ & $53.90^{\mathrm{a}}$ & $25.76^{b}$ & $3337^{a b}$ \\
\hline \multicolumn{2}{|c|}{$p$ value } & 0.0035 & $<0.0001$ & 0.3055 & 0.1301 & $<0.0001$ & $<0.0001$ & $<0.0001$ \\
\hline
\end{tabular}

Values with the same letter within each column are the same according to the Tukey $p \leq 0.05$.

\subsection{Nutrient Content}

The micronutrient concentrations are presented in Table 4 , where significant differences $(p \leq 0.05)$ were observed between the different foliar and edaphic zinc sulphate doses. The manganese concentration ranged between 7.74 and $12.64 \mathrm{ppm}$, with the lowest value found with the $0.500 \mathrm{~g}$ edaphic-25.0 mM foliar dose (7.74 ppm), while the $0.125 \mathrm{~g}$ edaphic-25.0 $\mathrm{mM}$ foliar dose produced the highest value (12.64 ppm). The copper concentration was higher $(9.94 \mathrm{ppm})$ with the $0.500 \mathrm{~g}$ edaphic- $25.0 \mathrm{mM}$ foliar dose compared to the control $(8.26 \mathrm{ppm})$. The iron concentration ranged between 40.96 and $56.95 \mathrm{ppm}$, with the highest concentration found with the $0.250 \mathrm{~g}$ edaphic- $50.0 \mathrm{mM}$ foliar dose, while the $0.125 \mathrm{~g}$ edaphic- $0.0 \mathrm{mM}$ foliar dose resulted in the lowest iron concentration. The application of the $0.125 \mathrm{~g}$ edaphic- $50.0 \mathrm{mM}$ foliar, $0.0 \mathrm{~g}$ edaphic- $50.0 \mathrm{mM}$ foliar, and $0.5 \mathrm{~g}$ edaphic- $12.5 \mathrm{mM}$ foliar doses of zinc sulphate produced zinc concentrations of 56.54, 55.55, and $55.28 \mathrm{ppm}$, respectively, while the $0.125 \mathrm{~g}$ edaphic- $0.0 \mathrm{mM}$ foliar dose and the control had the lowest zinc contents, with values of 48.86 and $47.77 \mathrm{ppm}$. However, in general, doses with some soil or foliar zinc sulphate content were statistically different $(p \leq 0.05)$ from the control dose. The nickel concentration ranged between 4.32 and $6.53 \mathrm{ppm}$, with the $0.125 \mathrm{~g}$ edaphic- $12.5 \mathrm{mM}$ foliar dose showing the highest concentration, while the control presented the lowest value. 
Table 4. Micronutrient concentration (ppm) in biofortified cowpea beans (Vigna unguiculata L. Walpers) with different zinc sulphate doses.

\begin{tabular}{|c|c|c|c|c|c|c|}
\hline \multicolumn{2}{|c|}{ Doses } & \multirow{2}{*}{ Manganese } & \multirow{2}{*}{ Copper } & \multirow{2}{*}{ Iron } & \multirow{2}{*}{ Zinc } & \multirow{2}{*}{ Nickel } \\
\hline Edaphic (g) & Foliar (mM) & & & & & \\
\hline 0 & 0 & $8.87^{\mathrm{d}}$ & $8.26^{b}$ & $42.94^{b c}$ & $47.77^{\mathrm{b}}$ & $4.32^{c}$ \\
\hline 0 & 12.5 & $12.30^{\mathrm{a}}$ & $9.31^{\mathrm{ab}}$ & $52.33^{a b}$ & $52.66^{\mathrm{ab}}$ & $4.75 \mathrm{bc}$ \\
\hline 0 & 25 & $10.88^{b c}$ & $9.24^{a b}$ & $43.17^{b c}$ & $52.75^{\mathrm{ab}}$ & $5.15^{a b c}$ \\
\hline 0 & 50 & $11.63^{\mathrm{ab}}$ & $9.24^{\mathrm{ab}}$ & $52.50^{\mathrm{ab}}$ & $55.55^{\mathrm{ab}}$ & $5.22 \mathrm{abc}$ \\
\hline 0.125 & 0 & $10.26^{b c}$ & $9.45^{a b}$ & $40.96^{c}$ & $48.46^{b}$ & $5.89 \mathrm{abc}$ \\
\hline 0.125 & 12.5 & $11.09^{a b}$ & $9.18^{a b}$ & $49.23^{a b c}$ & $51.15^{\mathrm{ab}}$ & $6.53^{a}$ \\
\hline 0.125 & 25 & $12.64^{\mathrm{a}}$ & $9.20^{a b}$ & $55.13^{\mathrm{a}}$ & $52.61^{\mathrm{ab}}$ & $5.72 \mathrm{abc}$ \\
\hline 0.125 & 50 & $9.05^{c d}$ & $8.93^{a b}$ & $45.81^{a b c}$ & $56.54^{\mathrm{a}}$ & $5.85^{a b c}$ \\
\hline 0.25 & 0 & $12.13^{a}$ & $9.78^{a b}$ & $55.09^{\mathrm{a}}$ & $50.24^{\mathrm{ab}}$ & $6.35^{\mathrm{ab}}$ \\
\hline 0.25 & 12.5 & $9.48^{\mathrm{cd}}$ & $9.44^{\mathrm{ab}}$ & $42.04^{b c}$ & $49.95^{\mathrm{ab}}$ & $6.26^{\mathrm{ab}}$ \\
\hline 0.25 & 25 & $11.03^{\mathrm{ab}}$ & $9.24^{\mathrm{ab}}$ & $49.50^{a b c}$ & $54.35^{\mathrm{ab}}$ & $5.99^{a b}$ \\
\hline 0.25 & 50 & $8.33^{\mathrm{d}}$ & $9.20^{a b}$ & $56.95^{\mathrm{a}}$ & $53.20^{\mathrm{ab}}$ & $6.16^{\mathrm{ab}}$ \\
\hline 0.5 & 0 & $8.71^{\mathrm{d}}$ & $9.59^{a b}$ & $50.92^{a b c}$ & $49.69^{a b}$ & $5.99 \mathrm{ab}$ \\
\hline 0.5 & 12.5 & $11.22^{a b}$ & $9.61^{\mathrm{ab}}$ & $55.51^{\mathrm{a}}$ & $55.28^{a b}$ & $6.23^{\mathrm{ab}}$ \\
\hline 0.5 & 25 & $7.74^{\mathrm{e}}$ & $9.94^{\mathrm{a}}$ & $41.65^{b c}$ & $49.00^{\mathrm{ab}}$ & $6.07^{a b}$ \\
\hline 0.5 & 50 & $10.35^{b c}$ & $9.77^{a b}$ & $49.08^{a b c}$ & $54.97^{\mathrm{ab}}$ & $5.69 \mathrm{abc}$ \\
\hline \multicolumn{2}{|c|}{$p$ value } & $<0.0001$ & 0.1213 & $<0.0001$ & 0.0454 & 0.0066 \\
\hline \multirow{4}{*}{ Edaphic } & 0 & $10.92^{a}$ & $9.01^{b}$ & $47.73^{a}$ & $52.18^{a}$ & $4.86^{b}$ \\
\hline & 0.125 & $10.76^{\mathrm{a}}$ & $9.19^{a b}$ & $47.78^{a}$ & $52.19^{a}$ & $6.00^{\mathrm{a}}$ \\
\hline & 0.25 & $10.24^{\mathrm{ab}}$ & $9.42^{\mathrm{ab}}$ & $50.90^{a}$ & $51.93^{\mathrm{a}}$ & $6.19^{\mathrm{a}}$ \\
\hline & 0.5 & $9.51^{b}$ & $9.73^{\mathrm{a}}$ & $49.29^{\mathrm{a}}$ & $52.24^{\mathrm{a}}$ & $6.00^{\mathrm{a}}$ \\
\hline \multicolumn{2}{|c|}{$p$ value } & 0.0066 & 0.0112 & 0.078 & 0.5409 & $<0.0001$ \\
\hline \multirow{5}{*}{ Foliar } & 0 & $9.99 \mathrm{ab}$ & $9.27^{\mathrm{a}}$ & $47.48^{\mathrm{ab}}$ & $49.04^{b}$ & $5.64^{\mathrm{a}}$ \\
\hline & 12.5 & $11.03^{a}$ & $9.39^{a}$ & $49.78^{a b}$ & $52.26^{\mathrm{a}}$ & $5.94^{\mathrm{a}}$ \\
\hline & 25 & $10.57^{a b}$ & $9.41^{\mathrm{a}}$ & $47.36^{b}$ & $52.18^{a}$ & $5.73^{\mathrm{a}}$ \\
\hline & 50 & $9.84^{b}$ & $9.29^{a}$ & $51.08^{\mathrm{a}}$ & $55.07^{\mathrm{a}}$ & $5.73^{\mathrm{a}}$ \\
\hline & $p$ value & 0.0255 & 0.8882 & 0.0212 & $<0.0001$ & 0.3812 \\
\hline
\end{tabular}

Values with the same letter within each column are the same according to the Tukey test $p \leq 0.05$.

The effects of the edaphic and foliar doses separately showed significant differences $(p \leq 0.05)$. The highest values of manganese were found in the doses of $0.0,0.125$, and $0.250 \mathrm{~g}$, which were significantly different in comparison to the dose of $0.500 \mathrm{~g}$ zinc sulphate edaphic. The values of copper and nickel increased with the zinc sulphate edaphic dose, with significant differences with respect to the control ( $0.0 \mathrm{~g}$ of zinc sulphate). For the iron and zinc content, there were no significant differences between the different doses of edaphic zinc sulphate and the control, but the $0.500 \mathrm{~g}$ dose had the highest value with 49.29 and $52.34 \mathrm{mg} \mathrm{kg}^{-1}$, respectively. For the copper, iron, and nickel content, no significant differences were observed between different doses of zinc sulphate foliar. For manganese, the 12.5, 25.0, and $0.0 \mathrm{~g}$ zinc sulphate foliar doses produced the highest values, which were significantly different to the dose of $50.0 \mathrm{mM}$. The zinc content was significantly different between the doses (12.5, 25.0, and $50.0 \mathrm{mM}$ of zinc sulphate) and the control, which had the lowest zinc content. In general, the highest dose of zinc sulphate applied in either an edaphic $(0.500 \mathrm{~g})$ or foliar $(50.0 \mathrm{mM})$ form, increasing the content of this nutrient in the grain.

Macronutrients concentrations exhibited significant differences $(p \leq 0.05)$ between the different doses of edaphic and foliar zinc (Table 5). The $0.250 \mathrm{~g}$ edaphic- $25.0 \mathrm{mM}$ foliar dose had a nitrogen content of $4.73 \%$ compared to the $0.250 \mathrm{~g}$ edaphic- $50.0 \mathrm{mM}$ foliar dose, which decreased the nitrogen content to $4.04 \%$, but the values of the different edaphic and foliar doses were not significantly different. The phosphorus content did not display significant differences between the edaphic and foliar doses of zinc sulphate, but the $0.0 \mathrm{~g}$ edaphic- $12.5 \mathrm{mM}$ foliar dose had the highest value of $0.117 \%$. The potassium 
content ranged between $0.337 \%$ and $1.127 \%$, with the highest values being obtained with the doses of 0.0 g edaphic- $12.5 \mathrm{mM}$ foliar, $0.125 \mathrm{~g}$ edaphic- $25.0 \mathrm{mM}$ foliar, and $0.250 \mathrm{~g}$ edaphic- $50.0 \mathrm{mM}$ foliar, with contents of $1.127 \%, 1.075 \%$, and $1.110 \%$, respectively. For calcium, the highest value was found with the 0.125 g edaphic- $50.0 \mathrm{mM}$ foliar dose, with a value of $0.405 \%$, while the 0.250 g edaphic- $12.5 \mathrm{mM}$ foliar dose decreased the calcium concentration to $0.150 \%$. For the magnesium content, values between $0.135 \%$ and $0.190 \%$ were found with the dose of $0.125 \mathrm{~g}$ edaphic- $0.0 \mathrm{mM}$ foliar, representing the maximum level of magnesium that was obtained, and with $0.500 \mathrm{~g}$ edaphic- $50.0 \mathrm{mM}$ foliar, the minimum value was acquired. The sodium values found were minimal, although there were significant differences $(p \leq 0.05)$ between the different doses, with values between $0.0049 \%$ and $0.0093 \%$.

Table 5. Macronutrient concentration (\%) in biofortified cowpea beans (Vigna unguiculata L. Walpers), with different doses of zinc sulphate.

\begin{tabular}{|c|c|c|c|c|c|c|c|}
\hline \multicolumn{2}{|c|}{ Doses } & \multirow{2}{*}{ Nitrogen } & \multirow{2}{*}{ Phosphorus } & \multirow{2}{*}{ Potassium } & \multirow{2}{*}{ Calcium } & \multirow{2}{*}{ Magnesium } & \multirow{2}{*}{ Sodium } \\
\hline Edaphic (g) & Foliar (mM) & & & & & & \\
\hline 0 & 0 & $4.14^{\mathrm{a}}$ & $0.112^{\mathrm{a}}$ & $0.490^{\mathrm{de}}$ & $0.190^{\mathrm{cd}}$ & $0.145^{b c}$ & $0.0078^{a b d}$ \\
\hline 0 & 12.5 & $4.15^{\mathrm{a}}$ & $0.117^{\mathrm{a}}$ & $1.127^{\mathrm{a}}$ & $0.152^{d}$ & $0.170^{a b c}$ & $0.0053^{\mathrm{d}}$ \\
\hline 0 & 25 & $4.26^{\mathrm{a}}$ & $0.105^{\mathrm{a}}$ & $0.445^{\mathrm{de}}$ & $0.277^{b c}$ & $0.177^{a b}$ & $0.0083^{a b c}$ \\
\hline 0 & 50 & $4.15^{\mathrm{a}}$ & $0.110^{a}$ & $0.942^{a b c}$ & $0.177^{\mathrm{cd}}$ & $0.157^{a b c}$ & $0.0088^{a b}$ \\
\hline 0.125 & 0 & $4.22^{\mathrm{a}}$ & $0.105^{\mathrm{a}}$ & $0.487^{\mathrm{cd}}$ & $0.255^{b c d}$ & $0.190^{\mathrm{a}}$ & $0.0064^{b c d}$ \\
\hline 0.125 & 12.5 & $4.48^{\mathrm{a}}$ & $0.110^{\mathrm{a}}$ & $0.680^{\text {cde }}$ & $0.350^{a b}$ & $0.162^{a b c}$ & $0.0093^{\mathrm{a}}$ \\
\hline 0.125 & 25 & $4.44^{\mathrm{a}}$ & $0.100^{\mathrm{a}}$ & $1.075^{\mathrm{ab}}$ & $0.237^{b c d}$ & $0.165^{a b c}$ & $0.0049^{\mathrm{d}}$ \\
\hline 0.125 & 50 & $4.16^{\mathrm{a}}$ & $0.110^{a}$ & $0.410^{\text {de }}$ & $0.405^{a}$ & $0.167^{a b c}$ & $0.0066^{\mathrm{abd}}$ \\
\hline 0.25 & 0 & $4.37^{\mathrm{a}}$ & $0.115^{\mathrm{a}}$ & $0.957^{a b c}$ & $0.227^{\mathrm{cd}}$ & $0.150 \mathrm{bc}$ & $0.0088^{a b}$ \\
\hline 0.25 & 12.5 & $4.21^{\mathrm{a}}$ & $0.107^{\mathrm{a}}$ & $0.377^{\mathrm{e}}$ & $0.150^{\mathrm{d}}$ & $0.162^{a b c}$ & $0.0056^{\mathrm{cd}}$ \\
\hline 0.25 & 25 & $4.73^{a}$ & $0.112^{\mathrm{a}}$ & 0.737 bcd & $0.222^{\mathrm{cd}}$ & $0.140^{c}$ & $0.0073^{a b d}$ \\
\hline 0.25 & 50 & $4.04^{\mathrm{a}}$ & $0.105^{\mathrm{a}}$ & $1.110^{\mathrm{a}}$ & $0.210^{\mathrm{cd}}$ & $0.152^{b c}$ & 0.0069 abd \\
\hline 0.5 & 0 & $4.10^{\mathrm{a}}$ & $0.115^{\mathrm{a}}$ & $0.435 \mathrm{de}$ & $0.182^{\mathrm{cd}}$ & $0.152^{b c}$ & $0.0056^{\mathrm{cd}}$ \\
\hline 0.5 & 12.5 & $4.18^{\mathrm{a}}$ & $0.117^{a}$ & $0.955^{a b c}$ & $0.230^{\mathrm{cd}}$ & $0.142^{b c}$ & $0.0074^{\mathrm{abcd}}$ \\
\hline 0.5 & 25 & $4.20^{\mathrm{a}}$ & $0.115^{\mathrm{a}}$ & $0.457^{\mathrm{de}}$ & $0.177^{\mathrm{cd}}$ & $0.162^{a b c}$ & $0.0053^{\mathrm{d}}$ \\
\hline \multirow[t]{2}{*}{0.5} & 50 & $4.13^{\mathrm{a}}$ & $0.115^{\mathrm{a}}$ & $0.665^{\text {cde }}$ & $0.257 \mathrm{bcd}$ & $0.135^{c}$ & $0.0091^{\mathrm{ab}}$ \\
\hline & lue & 0.2127 & 0.448 & $<0.0001$ & $<0.0001$ & 0.0001 & $<0.0001$ \\
\hline \multirow{4}{*}{ Edaphic } & 0 & $4.17^{\mathrm{a}}$ & $0.111^{a b}$ & $0.751^{a b}$ & $0.199^{b}$ & $0.162^{a b}$ & $0.0076^{a}$ \\
\hline & 0.125 & $4.32^{\mathrm{a}}$ & $0.106^{b}$ & $0.663^{a b}$ & $0.312^{a}$ & $0.171^{a}$ & $0.0068^{a}$ \\
\hline & 0.25 & $4.34^{\mathrm{a}}$ & $0.110^{a b}$ & $0.796^{a}$ & $0.202^{b}$ & $0.151^{b}$ & $0.0072^{\mathrm{a}}$ \\
\hline & 0.5 & $4.15^{\mathrm{a}}$ & $0.116^{\mathrm{a}}$ & $0.628^{b}$ & $0.212^{b}$ & $0.148^{b}$ & $0.0069^{\mathrm{a}}$ \\
\hline \multicolumn{2}{|c|}{$p$ value } & 0.2405 & 0.0258 & 0.0003 & $<0.0001$ & $<0.0001$ & 0.2554 \\
\hline \multirow{4}{*}{ Foliar } & 0 & $4.21^{\mathrm{a}}$ & $0.112^{a}$ & $0.592^{b}$ & $0.214^{b}$ & $0.159^{a}$ & $0.0072^{a b}$ \\
\hline & 12.5 & $4.25^{\mathrm{a}}$ & $0.113^{a}$ & $0.785^{a}$ & $0.221^{\mathrm{ab}}$ & $0.159^{a}$ & $0.0069 \mathrm{ab}$ \\
\hline & 25 & $4.41^{\mathrm{a}}$ & $0.108^{a}$ & $0.679 \mathrm{ab}$ & $0.229^{a b}$ & $0.161^{a}$ & $0.0065^{b}$ \\
\hline & 50 & $4.12^{\mathrm{a}}$ & $0.110^{a}$ & $0.782^{\mathrm{a}}$ & $0.262^{a}$ & $0.153^{a}$ & $0.0079^{a}$ \\
\hline \multicolumn{2}{|c|}{$p$ value } & 0.211 & 0.3644 & $<0.0001$ & 0.009 & 0.2562 & $<0.0001$ \\
\hline
\end{tabular}

Values with the same letter within each column are the same according to the Tukey test $p \leq 0.05$.

The individual effects of the edaphic and foliar doses showed significant differences $(p \leq 0.05)$ between the doses. The edaphic application for the nitrogen and sodium did not display significant differences between the edaphic doses of zinc sulphate, while for the phosphorus, potassium, calcium, and magnesium content, significant differences were found between doses. The edaphic application of $0.250 \mathrm{~g}$ had the highest nitrogen and potassium contents of 4.34 and $0.796 \%$, respectively, while $0.500 \mathrm{~g}$ produced the highest phosphorus concentration of $0.116 \%$. For the calcium and magnesium content, the highest value was found in the $0.125 \mathrm{~g}$ dose, with values of $3.81 \%$ and $53.57 \%$, respectively. For foliar application, the nitrogen, phosphorus, and magnesium content did not show significant differences between the doses of zinc sulphate, while for potassium and calcium, significant differences were found between the doses and the control $(0.0 \mathrm{~g})$, which had the minimum value. For foliar application, the highest contents of phosphorus and potassium were obtained with the dose of $12.5 \mathrm{mM}$, with values of $0.113 \%$ and $0.785 \%$, respectively, while the $25.0 \mathrm{mM}$ 
dose had the highest nitrogen and magnesium content, with values of $4.41 \%$ and $0.161 \%$, respectively. Additionally, for the $50 \mathrm{mM}$ foliar dose, the highest calcium and sodium contents were found, with values of $0.262 \%$ and $0.0079 \%$, respectively.

\subsection{Bioactive Compound Content and Antioxidant Capacity}

The bioactive compound content and antioxidant capacity showed significant differences $(p \leq 0.05)$ between the doses of edaphic and foliar zinc tested (Table 6). Total phenols ranged between 1.06 and $2.03 \mathrm{mg} \mathrm{GA} \mathrm{g}^{-1} \mathrm{PS}$, while the $0.250 \mathrm{~g}$ edaphic- $0.0 \mathrm{mM}$ foliar and $0.125 \mathrm{~g}$ edaphic- $50.0 \mathrm{mM}$ foliar doses produced the highest values of 1.97 and $2.03 \mathrm{mg} \mathrm{GA} \mathrm{g}^{-1} \mathrm{PS}$, respectively. The lowest flavonoid content was obtained with the $0.0 \mathrm{~g}$ edaphic- $25.0 \mathrm{mM}$ foliar dose, with $0.50 \mathrm{mg}$ EC $\mathrm{g}^{-1} \mathrm{PS}$, and increased with the $0.500 \mathrm{~g}$ edaphic- $25.0 \mathrm{mM}$ foliar, $0.500 \mathrm{~g}$ edaphic-50.0 mM foliar, 0.125 g edaphic- $25.0 \mathrm{mM}$ foliar, and 0.125 g edaphic- $50.0 \mathrm{mM}$ foliar doses $(0.82,0.83,0.70$, and $0.69 \mathrm{mg}$ $\mathrm{CE} \mathrm{g}^{-1} \mathrm{PS}$, respectively). The anthocyanin content ranged between 0.96 and $1.28 \mathrm{mg} \mathrm{C}^{\mathrm{G}} \mathrm{G} \mathrm{g}^{-1} \mathrm{PS}$. The highest values were obtained with $0.250 \mathrm{~g}$ edaphic- $12.5 \mathrm{mM}$ foliar, $0.0 \mathrm{~g}$ edaphic-50.0 mM foliar, $0.125 \mathrm{~g}$ edaphic- $25.0 \mathrm{mM}$ foliar, and $0.250 \mathrm{~g}$ edaphic- $0.0 \mathrm{mM}$ foliar doses, with $1.28,1.26,1.26$, and $1.25 \mathrm{mg} \mathrm{C} \mathrm{G} \mathrm{g} \mathrm{g}^{-1}$ PS, respectively. The inhibition percentage of the antioxidant capacity in the different edaphic and foliar doses ranged from 86.49 to $89.60 \%$, with the highest antioxidant capacity presenting at the $0.0 \mathrm{~g}$ edaphic- $50.0 \mathrm{mM}$ foliar dose. However, this was statistically equal to the $0.500 \mathrm{~g}$ edaphic-25.0 mM foliar, 0.125 g edaphic- $0.0 \mathrm{mM}$ foliar, $0.500 \mathrm{~g}$ edaphic-50 mM foliar, and $0.250 \mathrm{~g}$ edaphic- $50.0 \mathrm{mM}$ foliar doses, with values of $89.12,89.01,88.61$, and $88.30 \%$, respectively, compared to the 0.0 g edaphic- $0.0 \mathrm{mM}$ foliar dose, which resulted in a value of $86.57 \%$.

Regarding the effects of the edaphic and foliar doses, significant differences $(p \leq 0.05)$ were observed between zinc doses. At the edaphic level, the dose with the highest total phenol content was the $0.125 \mathrm{~g}$ edaphic dose, with $1.72 \mathrm{mg} \mathrm{GA} \mathrm{g}^{-1}$ PS. For flavonoids, it was the dose of $0.500 \mathrm{~g}$, with $0.75 \mathrm{mg} \mathrm{EC} \mathrm{g}^{-1}$ PS. At the foliar level, the total phenol content with the $50.0 \mathrm{mM}$ dose was $1.64 \mathrm{mg}$ $\mathrm{GA} \mathrm{g}^{-1} \mathrm{PS}$; the $50.0 \mathrm{mM}$ dose produced $0.71 \mathrm{mg} \mathrm{EC} \mathrm{g}^{-1} \mathrm{PS}$ of flavonoids, which was equal to the dose with $25.0 \mathrm{mM}$ foliar. For the $0.50 \mathrm{mM}$ dose, an antioxidant capacity with $88.68 \%$ inhibition stood out. 
Table 6. The bioactive compound concentration and antioxidant capacity in biofortified cowpea beans (Vigna unguiculata L. Walpers) with different doses of zinc sulphate.

\begin{tabular}{|c|c|c|c|c|c|}
\hline \multicolumn{2}{|c|}{ Doses } & \multirow{2}{*}{$\begin{array}{l}\text { Total Phenols } \\
\text { (mg GA g } \text { g }^{-1} \text { PS) }\end{array}$} & \multirow{2}{*}{$\begin{array}{c}\text { Flavonoids } \\
\left(\mathrm{mg} \mathrm{CE}^{-1} \text { PS) }\right.\end{array}$} & \multirow{2}{*}{$\begin{array}{l}\text { Anthocyanins } \\
\text { (mg C3G g }{ }^{-1} \text { PS) }\end{array}$} & \multirow{2}{*}{$\begin{array}{c}\text { Antioxidant Capacity } \\
\text { (\% Inhibition) }\end{array}$} \\
\hline Edaphic (g) & Foliar (mM) & & & & \\
\hline 0 & 0 & $1.58^{b c}$ & $0.57^{\mathrm{cd}}$ & $0.96^{\mathrm{b}}$ & 86.57 de \\
\hline 0 & 12.5 & $1.51^{b c}$ & $0.61^{\mathrm{bcd}}$ & $1.05^{\mathrm{ab}}$ & $88.05^{b c}$ \\
\hline 0 & 25 & $1.54 \mathrm{bc}$ & $0.50^{\mathrm{d}}$ & $1.18^{a b}$ & $87.88^{\text {bcd }}$ \\
\hline 0 & 50 & $1.76^{a b}$ & $0.59^{\mathrm{cd}}$ & $1.26^{\mathrm{a}}$ & $89.60^{a}$ \\
\hline 0.125 & 0 & $1.62^{b c}$ & $0.65^{b c}$ & $1.20^{\mathrm{ab}}$ & $89.01^{a b}$ \\
\hline 0.125 & 12.5 & $1.52^{b c}$ & $0.63^{b c}$ & $1.21^{\mathrm{ab}}$ & $87.46^{\text {cde }}$ \\
\hline 0.125 & 25 & $1.70^{\mathrm{b}}$ & $0.70^{a b c}$ & $1.26^{\mathrm{a}}$ & $87.26^{\text {cde }}$ \\
\hline 0.125 & 50 & $2.03^{a}$ & $0.69^{a b c}$ & $1.11^{\mathrm{ab}}$ & $88.21^{b c}$ \\
\hline 0.25 & 0 & $1.97^{\mathrm{a}}$ & $0.63^{b c}$ & $1.25^{\mathrm{a}}$ & $88.01^{b c}$ \\
\hline 0.25 & 12.5 & $1.15^{\mathrm{de}}$ & $0.68^{b c}$ & $1.28^{\mathrm{a}}$ & $88.04^{b c}$ \\
\hline 0.25 & 25 & $1.06^{\mathrm{e}}$ & $0.63^{b c}$ & $1.11^{\mathrm{ab}}$ & 87.30 cde \\
\hline 0.25 & 50 & $1.16^{\mathrm{de}}$ & $0.74^{\mathrm{ab}}$ & $1.05^{\mathrm{ab}}$ & $88.30^{a b c}$ \\
\hline 0.5 & 0 & $1.41^{\mathrm{cd}}$ & $0.67^{b c}$ & $1.22^{\mathrm{ab}}$ & $87.45^{\text {cde }}$ \\
\hline 0.5 & 12.5 & $1.07^{\mathrm{e}}$ & $0.69^{b c}$ & $1.19^{a b}$ & $86.49^{\mathrm{e}}$ \\
\hline 0.5 & 25 & $1.53^{b c}$ & $0.82^{\mathrm{a}}$ & $1.13^{\mathrm{ab}}$ & $89.12^{a b}$ \\
\hline 0.5 & 50 & $1.19 \mathrm{de}$ & $0.83^{a}$ & $1.19^{\mathrm{ab}}$ & $88.61^{a b c}$ \\
\hline \multicolumn{2}{|c|}{$p$ value } & $<0.0001$ & $<0.0001$ & 0.0724 & 0.877 \\
\hline \multirow{4}{*}{ Edaphic } & 0 & $1.60^{b}$ & $0.57^{c}$ & $1.11^{\mathrm{a}}$ & $88.02^{a}$ \\
\hline & 0.125 & $1.72^{\mathrm{a}}$ & $0.67^{b}$ & $1.20^{\mathrm{a}}$ & $87.99^{a}$ \\
\hline & 0.25 & $1.34^{\mathrm{c}}$ & $0.67^{b}$ & $1.17^{\mathrm{a}}$ & $87.91^{a}$ \\
\hline & 0.5 & $1.30^{c}$ & $0.75^{\mathrm{a}}$ & $1.18^{\mathrm{a}}$ & $87.92^{a}$ \\
\hline \multicolumn{2}{|c|}{$p$ value } & $<0.0001$ & $<0.0001$ & 0.0724 & 0.877 \\
\hline \multirow{4}{*}{ Foliar } & 0 & $1.54^{\mathrm{b}}$ & $0.63^{b}$ & $1.16^{\mathrm{a}}$ & $87.51^{b}$ \\
\hline & 12.5 & $1.31^{\mathrm{c}}$ & $0.66^{b}$ & $1.18^{\mathrm{a}}$ & $87.76^{b}$ \\
\hline & 25 & $1.46^{\mathrm{b}}$ & $0.67^{a b}$ & $1.17^{\mathrm{a}}$ & $87.89^{b}$ \\
\hline & 50 & $1.64^{\mathrm{a}}$ & $0.71^{\mathrm{a}}$ & $1.15^{\mathrm{a}}$ & $88.68^{a}$ \\
\hline \multicolumn{2}{|c|}{$p$ value } & $<0.0001$ & $<0.0001$ & 0.8313 & $<0.0001$ \\
\hline
\end{tabular}

Values with the same letter within each column are the same according to the Tukey test $p \leq 0.05$.

\section{Discussion}

\subsection{Physical Characteristics of the Grain}

The grain sizes (length, width, and thickness) of all the zinc edaphic and foliar doses are within the reported sizes [36]. However, the weight of 100 grains was higher than the 11 g reported [37]; it was within the range reported for zinc biofortified cowpea beans (Vigna unguiculata L. Walpers) (11.8 and $16.7 \mathrm{~g}$ ) [38]. This agrees with studies that have indicated that zinc application increases the yield and compounds in cultivated plants [39]. The size of the grain is an important criterion for consumers, as small grains are associated with a shorter cooking time [40]. This increase may be due to zinc's role in maturation processes and seed production in plants, which affects the performance. With separate doses, $0.250 \mathrm{~g}$ of edaphic zinc produced grains with the largest sizes and weight of 100 grains, although there were no statistical differences, while with the $12.5 \mathrm{mM}$ foliar dose, grains had the greatest widths, thicknesses, and weights. This is corroborated when observing the highest values in grain dimensions and weight with the $0.250 \mathrm{~g}$ edaphic- $12.5 \mathrm{mM}$ foliar dose, which coincides with Sida-Arreola et al. [41], who reported that adequate zinc application increases the production of grain in legumes. Furthermore, Yashona et al. [42] reported that the simultaneous edaphic and foliar application of zinc had a better effect on the performance than carrying out the applications separately.

\subsection{Physicochemical Composition}

The ash content was similar to another report [43], and the highest content (4\%) was obtained with the 0.500 g edaphic- $12.5 \mathrm{mM}$ foliar, $0.500 \mathrm{~g}$ edaphic- $25.0 \mathrm{mM}$ foliar, $0.250 \mathrm{~g}$ edaphic- $12.5 \mathrm{mM}$ foliar, and 0.500 edaphic- $50.0 \mathrm{mM}$ foliar doses, indicating that these doses contained the highest nutrient contents (Table 3). For the fat content, 11 doses had values higher than the mean of $1.4 \%$ reported for 
cowpea beans [43]. However, only the 0.250 g edaphic- $12.5 \mathrm{mM}$ foliar and 0.250 g edaphic- $25.0 \mathrm{mM}$ foliar doses had values greater than the $1.92 \%$ reported by Antova et al. [44] for cowpea bean varieties, indicating that these doses increased the grain fat content, which may be associated with benefits for human health [45]. The individual effects of the edaphic and foliar zinc doses produced an increase in fat content, which increased up to $0.250 \mathrm{~g}$ with the edaphic dose, but when the dose increased to $0.500 \mathrm{~g}$, the content decreased. Additionally, with the foliar dose, the highest content was obtained with the 12.5.0 mM dose, although the contents of the 25.0 and $50.0 \mathrm{mM}$ foliar doses were statistically similar. The moisture and fiber content showed no differences between the doses, but the values were within those previously reported for these variables [46].

The carbohydrate content increased with increasing edaphic and foliar doses, showing that zinc increases the carbohydrate content in cowpea beans, and the $0.250 \mathrm{~g}$ edaphic- $50.0 \mathrm{mM}$ foliar dose produced the highest carbohydrate content. Many zinc-dependent enzymes are involved in carbohydrate metabolism, so zinc is involved in starch formation [47]. Protein contents between 25.27 and $29.58 \%$ were found, which were higher than the $23.90 \%$ protein reported for cowpea beans [36] and the control $(0.0 \mathrm{~g}$ edaphic- $0.0 \mathrm{mM}$ foliar). Higher protein contents may have been found in most of the edaphic and foliar zinc doses, because zinc is an important nutrient that influences protein synthesis [48]; therefore, the different zinc doses were able to increase the content. Zinc is very closely involved in the $\mathrm{N}$ metabolism of plants. In zinc-deficient plants, protein synthesis and protein levels are markedly reduced, and amino acids and amides are accumulated [49]. The nutritional content of the cowpea bean is based on its protein and carbohydrate content; the protein content is the greatest advantage for human consumption [50]. The WHO [9] advises that the daily protein requirement for adults, including pregnant or lactating women, is $0.66 \mathrm{~g} \mathrm{~kg}^{-1}$, or $105 \mathrm{mg}$ of nitrogen $\mathrm{kg}^{-1}$ of body weight. Therefore, with an intake of around $100 \mathrm{~g}$ of grains with over $27 \%$ protein, the daily requirement for protein intake is met. For the individual effects, no differences were observed between the edaphic doses, but the highest protein content was found with $0.250 \mathrm{~g}$, while in the foliar form, it was obtained at the $25.0 \mathrm{mM}$ dose. This is corroborated by simultaneously applying these doses ( $0.250 \mathrm{~g}$ of edaphic- $25.0 \mathrm{mM}$ foliar), increasing the value to a content of $29.59 \%$ for protein. In zinc-deficient plants, the rate of protein synthesis and the protein concentration are strongly reduced, and a high zinc requirement for protein synthesis has also been shown in pollen tubes [51]. The energy content ranged between 3304 and $3389 \mathrm{kcal} \mathrm{kg}^{-1}$, which depended on the carbohydrate and protein content, which were within the values reported for cowpea beans [52]. For the energy content, it was found that the values were within the reported range [45], but it was observed that the highest energy values were obtained with the doses that presented the highest protein and fat content, due to the relationship of these with the energy of the food.

\subsection{Nutrient Content}

Nutrient uptake by crop plants is influenced by climatic, soil, and plant factors. In Table 4, the contents of magnesium, copper, iron, zinc, and nickel are shown. Manganese and copper are important for redox systems; as activators of various enzymes, iron plays a crucial role in redox systems in cells and in various enzymes, zinc plays a role in the detoxification of superoxide radicals, membrane integrity as well as the synthesis of proteins and the phytohormone IAA, nickel is involved in nitrogen metabolism as metal component of the enzyme urease [51]. In grains, most of the zinc and other nutrients are localized in protein bodies and there is a very high positive correlation between the concentration of zinc, iron, and protein in seeds [51]. The highest zinc content in the grains was $56.54 \mathrm{ppm}$, with the $0.125 \mathrm{~g}$ edaphic- $50.0 \mathrm{mM}$ foliar dose. This value is low compared to the $71.2 \mathrm{ppm}$ reported for zinc sulphate biofortified cowpea beans [5]. In this sense, zinc mobility in soils is important in relation to zinc availability, since the zinc concentrations in soil solution are low [49]. In general, the zinc concentrations of all doses had contents lower than the $61 \mathrm{ppm}$ established as a critical level in plants, in order to have sufficient zinc as a nutrient [53]. Some researchers reported that the foliar application of EDTA chelated zinc could also increase grain zinc concentrations, but we 
chose to use zinc sulphate, since it was more economical [16]. These differences may be because the present work was carried out under field conditions, while the work that reported high contents was performed under greenhouse conditions and an inert substrate. The plant variety and the environmental and soil conditions could result in a lower content of zinc in the grain [54]. For example, during the first, third, and fourth zinc applications, there was rainfall (Figure 1), which could have influenced edaphic and foliar absorption. In addition, the iron content in the soil (Table 1) could have interfered with the zinc absorption by antagonism of these nutrients [55]. The individual effects of $0.500 \mathrm{~g}$ edaphic and $50.0 \mathrm{mM}$ foliar doses produced the highest zinc contents in the grains. However, for the edaphic application, there were no statistical differences between the different doses, while with the foliar doses, zinc contents were higher than the dose in which only water was applied. The manganese and copper contents were within the range reported by Guillén-Molina et al. [38] for cowpea beans. For the iron content, the values found were within the range of 48 to $79 \mathrm{ppm}$, reported by Timko and Singh [52] for cowpea beans. In general, it was observed that the average iron content in the grain was lower than the zinc content, although it was adequately found in the soil (Table 1), which may be because of the antagonism of iron and zinc [55]. Nickel values ranged between 4.32 and $6.53 \mathrm{ppm}$, with the highest content being obtained with $0.250 \mathrm{~g}$ applied edaphically and $12.5 \mathrm{mM}$ with the foliar form.

Nitrogen plays a central role in plant metabolism, as a constituent of proteins, nucleic acids, chlorophyll, coenzymes, phytohormones and secondary metabolites; phosphorus is a structural element in nucleic acids and plays a key role in energy transfer as a component of adenosine phosphates, and it is also essential for transfer of carbohydrates in leaf cells; potassium affects loading of sucrose and the rate of mass flow-driven solute movement within the plant; calcium is important for cell wall and membrane stabilization, osmoregulation and as second messenger allowing plants to regulate developmental processes in response to environmental stimuli; magnesium is a component of chlorophyll and is required for photosynthesis and protein synthesis [56]; sodium can also replace potassium in its role as osmoticum [57]. For the nitrogen content, no differences were found between the tested doses of edaphic and foliar zinc, but in general, the values obtained were among those reported for zinc biofortified cowpea beans $[5,38,58]$, but were higher than the content reported for unfortified cowpea beans (4.01\%) [44]. The calcium content ranged between 0.150 and $0.405 \%$, which is lower than the range of 0.85 to $1.40 \%$ reported for cowpea bean cultivars [59]. This may be due to the antagonistic effect between calcium and zinc [55]. Phosphorus and magnesium contents were low relative to those reported for cowpea beans, perhaps because the zinc application interferes with the absorption and translocation of these nutrients [60]. Variations may be due to slight toxicity in the presence of the highest zinc dose, especially with foliar fertilization at the doses of 25.0 and $50.0 \mathrm{mM} \mathrm{L}^{-1}$, which resulted in necrosis problems in young leaves and less growth of the plants in the first application. Regarding the separate doses, no dose had better results in terms of macronutrient contents, since, with the $0.125 \mathrm{~g}$ edaphic dose, the highest content of calcium and magnesium was obtained, while with the $0.250 \mathrm{~g}$ edaphic dose, there was a higher nitrogen and potassium content. The same thing happened for foliar doses, since the highest content of phosphorus and potassium was obtained with the $12.5 \mathrm{mM}$ dose, while with the $25.0 \mathrm{mM}$ dose, the highest contents of nitrogen and magnesium were observed, and with the $50 \mathrm{mM}$ dose, the highest contents of calcium and sodium were measured.

\subsection{Bioactive Compounds and Antioxidant Capacity}

The total phenolic content varied between 1.06 and $2.03 \mathrm{mg} \mathrm{GA} \mathrm{g}^{-1} \mathrm{PS}$, with the highest content being achieved with the $0.125 \mathrm{~g}$ edaphic- $50.0 \mathrm{mM}$ foliar dose. In this regard, Andresen et al. [61] reported that, due to their phenolic content, legumes can be classified as having low $\left(<1.0 \mathrm{mg} \mathrm{GAE} \mathrm{g}^{-1}\right)$, moderate $\left(1.0-2.0 \mathrm{mg} \mathrm{GAE} \mathrm{g}^{-1}\right)$, and high $\left(>2.0 \mathrm{mg} \mathrm{GAE} \mathrm{g}^{-1}\right)$ contents. For the control and some of the fourteen treatment doses with edaphic and/or foliar contents, the phenolic content of cowpea bean can be classified as having a moderate content, while the dose that produced the highest content would be classified as high. Except for the dose with a high phenolic content, the results of the other doses 
coincide with the moderate content of phenolic compounds reported for cowpea beans [5]. Human health is tied to plant phenolics; in this sense, zinc application is associated with increased activities of enzymes of the secondary pathway, namely shikimate dehydrogenase, phenylalanine ammonia-lyase, and polyphenols oxidase [11]. For the flavonoid content, the highest values were obtained with the doses with the highest content of edaphic zinc $(0.500 \mathrm{~g})$ and with the 25.0 and $50.0 \mathrm{mM}$ foliar doses, but in general, all doses had contents higher than the range of 0.0644 to 0.458 reported for cowpea bean [5]. For anthocyanins, the results ranged from 0.96 to $1.28 \mathrm{mg} \mathrm{C}^{3} \mathrm{G} \mathrm{g}^{-1} \mathrm{PS}$, with the highest content being produced with the $0.250 \mathrm{~g}$ edaphic- $12.5 \mathrm{mM}$ foliar dose. In general, the anthocyanin values are between the range of 0.875 and $3.86 \mathrm{mg} \mathrm{g}^{-1} \mathrm{PS}$ reported [1]. The antioxidant capacity values were between 86.49 and $89.60 \%$ of inhibition; the antioxidant capacity is related to the content of total phenols, flavonoids, and anthocyanins. This is because the doses that presented the highest antioxidant capacity had a higher content of these bioactive compounds, while the dose with the lowest content of bioactive compounds also presented the lowest antioxidant activity ( $0.500 \mathrm{~g}$ edaphic- $12.5 \mathrm{mM}$ foliar). The content of total phenols increased with low zinc doses $(0.125 \mathrm{~g}$ edaphic-0.0 mM foliar), while the content of flavonoids increased with the highest zinc doses $(0.500 \mathrm{~g}$ edaphic-50.0 mM foliar). For anthocyanins, no effect on the edaphic or foliar dose was observed, while for the antioxidant capacity, no edaphic dose produced statistical differences. When applying zinc in a foliar way, it was observed that the antioxidant capacity increased with the doses, with the highest percentage of inhibition showing the dose of $50.0 \mathrm{mM}$ foliar, which coincides with those who have reported that the antioxidant capacity increases with the application of foliar zinc [11].

\section{Conclusions}

The agronomic biofortification of cowpea beans with different edaphic and foliar doses of zinc sulphate influenced the size, physicochemical composition, nutrient content, bioactive compounds, and antioxidant capacity of the cowpea (Vigna unguicula L. Walpers) grains. The largest grain sizes were obtained with the application of $0.250 \mathrm{~g}$ edaphic in combination with $12.5 \mathrm{mM}$ foliar doses, while the highest fat, carbohydrate, and protein contents were found with the $0.250 \mathrm{~g}$ edaphic dose. In the foliar treatment, the highest protein content was $25.0 \mathrm{mM}$. Grain zinc contents higher than 48 ppm were obtained with all edaphic applications, alone or in combination with foliar applications, and the highest zinc content was obtained with the dose of $0.125 \mathrm{~g}$ edaphic- $50.0 \mathrm{mM}$ foliar. Serving cowpea grains from the $0.250 \mathrm{~g}$ edaphic-50.0 $\mathrm{mM}$ foliar dose could provide a marked amount of the daily zinc for people. For the content of bioactive compounds, the different edaphic doses did not affect the anthocyanin content and antioxidant capacity, but with the $0.125 \mathrm{~g}$ edaphic dose, the highest total phenolic content was obtained. However, for the foliar application, it was observed that the $50.0 \mathrm{mM}$ dose increases the flavonoid content and antioxidant capacity. The foliar dose of $0.0 \mathrm{~g}$ and edaphic-50.0 $\mathrm{mM}$ had the highest antioxidant capacity. Edaphic and foliar zinc biofortification in field cowpea is an effective tool for increasing the zinc content in grains and thus helping to combat micronutrient malnutrition.

Author Contributions: D.L.-M., methodology, visualization, and writing—review and editing; C.M.-Q., validation, writing-original draft, and writing-review and editing; E.S.-C., formal analysis, project administration, and writing-review and editing; P.P.-R., project administration, software, and supervision; R.O.-O., investigation and writing - review and editing; E.d.l.C.-L., conceptualization, methodology, project administration, resources, and writing-review and editing. All authors have read and agreed to the published version of the manuscript.

Funding: This work has been supported by grants of the UJAT no. 519 and 549.

Acknowledgments: David López Morales gives thanks for the scholarship granted by the National Council of Science and Technology (CONACYT) of Mexico. The authors appreciate the collaboration and assistance of M.C. Ezequiel Muñoz-Márquez, technician of the Laboratory of Plant Physiology and Nutrition of the Centre for Research in Food and Development, A.C. Delicias Unit, Chihuahua, Mexico.

Conflicts of Interest: The authors declare no conflict of interest. 


\section{References}

1. Awika, J.M.; Duodu, K.G. Bioactive polyphenols and peptides in cowpea (Vigna unguiculata) and their health promoting properties: A review. J. Funct. Foods 2017, 38, 686-697. [CrossRef]

2. Boukar, O.; Belko, N.; Chamarthi, S.; Togola, A.; Batieno, J.; Owusu, E.; Haruna, M.; Diallo, S.; Umar, M.L.; Olufajo, O.; et al. Cowpea (Vigna unguiculata): Genetics, genomics and breeding. Plant Breed. 2018, 134, 415-424. [CrossRef]

3. Moreira-Araújo, R.S.R.; Sampaio, G.R.; Manólio-Soares, R.A.; Pereira-Silva, R.; Pereira-Silva, J.A. Identification and quantification of antioxidant compounds in cowpea. Rev. Ciên. Agron. 2017, 48, 799-805. [CrossRef]

4. Alloway, B.J. Bioavailability of elements in soil. In Essentials of Medical Geology: Revised Edition; Selinus, O., Alloway, B., Centeno, J.A., Finkelman, R.B., Fuge, R., Lindh, U., Smedley, P., Eds.; Springer: Dordrecht, The Netherlands, 2013; pp. 351-373. [CrossRef]

5. Estrada-Domínguez, V.; Sánchez-Chávez, E.; de-la-Cruz-Lázaro, E.; Márquez-Quiroz, C.; Osorio-Osorio, R. Effect of zinc chelate and sulfate on mineral content, antioxidant activity and grain yield of Vigna unguiculata L. Philipp. Agric. Sci. 2020, 103, 47-54.

6. Hefferon, K. Biotechnological approaches for generating zinc-enriched crops to combat maulnutrition. Nutrients 2019, 11, 253. [CrossRef]

7. Melo, F.B.; Bastos, E.A.; Cardoso, M.J.; Ribeiro, V.Q. Cowpea response to phosphorus and zinc. Rev. Caatinga 2018, 31, 240-245. [CrossRef]

8. Poniedziałek, B.; Perkowska, K.; Rzymski, P. Food fortification. In Vitamins and Minerals Biofortification of Edible Plants; Benkeblia, N., Ed.; Willey Blackwell: Hoboken, NJ, USA, 2020; pp. 27-44. [CrossRef]

9. World Health Organization (WHO). Protein and Amino Acid Requirements in Human Nutrition: Report of a Joint FAO/WHO/UNU Expert Consultation; WHO Technical Report Series; WHO: Geneva, Switzerland, 2007; Available online: https:/www.who.int/nutrition/publications/nutrientrequirements/WHO_TRS_935/en/ (accessed on 18 September 2019).

10. Sida-Arreola, J.P.; Sánchez, E.; Ojeda-Barrios, D.L.; Ávila-Quezada, G.D.; Flores-Córdova, M.A.; Márquez-Quiroz, C.; Preciado-Rangel, P. Can biofortification of zinc improve the antioxidant capacity and nutritional quality of beans? Emir. J. Food Agric. 2017, 29, 237-241. [CrossRef]

11. Majdoub, N.; el-Guendouz, S.; Rezgui, M.; Carlier, J.; Costa, C.; Kaab, L.B.B.; Miguel, M.G. Growth, photosynthetic pigments, phenolic content and biological activities of Foeniculum vulgare Mill., Anethum graveolens L. and Pimpinella anisum L. (Apiaceae) in response to zinc. Ind. Crops Prod. 2017, 109, 627-636. [CrossRef]

12. Tsonev, T.; Cebola, L.F.J. Zinc in plants-An overview. Emir. J. Food Agric. 2012, 24, 322-333.

13. Sadeghzadeh, B.; Rengel, Z. A review of zinc nutrition and plant breeding. J. Soil Sci. Plant Nutr. 2013, 13, 905-927. [CrossRef]

14. Gomathi, M.; Vethamoni, P.I.; Gopinath, P. Biofortification in vegetable crops-A review. Chem. Sci. Rev. Lett. 2017, 6, 1227-1237.

15. Jha, A.B.; Warkentin, T.D. Biofortification of pulse crops: Status and future perspectives. Plants 2020, 9, 73. [CrossRef]

16. Doolette, C.L.; Read, T.L.; Li, C.; Scheckel, K.G.; Donner, E.; Kopittke, P.M.; Schjoerring, J.K.; Lombi, E. Foliar application of zinc sulphate and zinc EDTA to wheat leaves: Differences in mobility, distribution, and speciation. J. Exp. Bot. 2018, 69, 4469-4481. [CrossRef] [PubMed]

17. White, P.J.; Thompson, J.A.; Wright, G.; Rasmussen, S.K. Biofortifying Scottish potatoes with zinc. Plant Soil 2017, 411, 151-165. [CrossRef]

18. Niyigaba, E.; Twizerimana, A.; Mugenzi, I.; Ngnadong, W.A.; Ye, Y.P.; Wu, B.M.; Hai, J.B. Winter wheat grain quality, zinc and iron concentration affected by a combined foliar spray of zinc and iron fertilizers. Agronomy 2019, 9, 250. [CrossRef]

19. Cakmak, I. Enrichment of cereal grains with Zinc: Agronomic or genetic biofortification? Plant Soil 2008, 302, 1-17. [CrossRef]

20. Potarzycki, J.; Przygocka, C.K.; Grzebisz, W.; Szczepaniak, W. Effect of zinc application timing on yield formation by two types of maize cultivars. Plant Soil Environ. 2015, 61, 468-474. [CrossRef]

21. Manna, D.; Maity, T.K. Growth, yield and bulb quality of onion (Allium cepa L.) in response to foliar application of boron and zinc. J. Plant Nutr. 2016, 39, 438-441. [CrossRef] 
22. Movahhedy, D.M.; Modarres, S.S.A.M.; Mokhtassi, B.A. Foliar application of zinc and manganese improves seed yield and quality of safflower (Carthamus tinctorius L.) grown under water deficit stress. Ind. Crops Prod. 2009, 30, 82-92. [CrossRef]

23. Manzeke, M.G.; Mtambanengwe, F.; Nezomba, H.; Watts, M.J.; Broadley, M.R.; Mapfumo, P. Zinc fertilization increases productivity and grain nutritional quality of cowpea (Vigna unguiculata (L.) Walp.) under integrated soil fertility management. Field Crops Res. 2017, 213, 231-244. [CrossRef]

24. NOM-021-RECNAT-2000 Norma Oficial Mexicana. NOM-021-RECNAT-2000, Que Establece las Especificaciones de Fertilidad, Salinidad y Clasificación de Suelos, Estudios, Muestreo y Anaálisis. 2002. Available online: http://www.ordenjuridico.gob.mx/Documentos/Federal/wo69255.pdf (accessed on 20 March 2019).

25. Báez, A.; Hernández, C.A. Estudio del rendimiento de cultivares de frijol caupí (Vigna unguiculata (L.) Walp.) en diferentes épocas de siembra en Camajuaní, Cuba. Rev. Cienc. Tecnol. 2016, 18, 11-18.

26. NMX-F-066-S-1978. Alimentos. Determinación de Cenizas en Alimentos. Normas Mexicanas. Dirección General de Normas. Available online: http://www.colpos.mx/bancodenormas/nmexicanas/NMX-F-066-S1978.PDF (accessed on 20 March 2019).

27. NMX-F-427-1982. Alimentos. Determinación de Grasa (Método de Hidrólisis ácida). Foods. Determination of Fat (Acid Hydrolysis Method). Normas Mexicanas. Dirección General de Normas. 1982. Available online: http://www.colpos.mx/bancodenormas/nmexicanas/NMX-F-427-1982.PDF (accessed on 20 March 2019).

28. NOM-F-90-S-1978. Determinación de Fibra Cruda en Alimentos. Foodstuff Determination of Crude Fiber. Norma Oficial Mexicana. Available online: https://www.colpos.mx/bancodenormas/nmexicanas/NMX-F090-S-1978.PDF (accessed on 20 March 2019).

29. Association of Official Analytical Chemist (AOAC). Official Methods of Analysis of AOAC International, 17th ed.; AOAC: Oakville, MD, USA, 2000.

30. Calvo, N.I.R.; Echeverría, H.E.; Rozas, H.S. Comparación de métodos de determinación de nitrógeno y azufre en planta: Implicancia en el diagnóstico de azufre en trigo. Cienc. Suelo 2008, 26, 161-167.

31. NOM-051-SCFI/SSA1-2010. Especificaciones Generales de Etiquetado Para Alimentos Y Bebidas No Alcohólicas Preenvasados-Información Comercial Y Sanitaria. Available online: http://dof.gob.mx/nota_ detalle.php?codigo=5137518\&fecha=05/04/2010 (accessed on 20 March 2019).

32. Hsu, C.L.; Chen, W.; Weng, Y.M.; Tseng, C.Y. Chemical composition, physical properties, and antioxidant activities of yam flours as affected by different drying methods. Food Chem. 2003, 83, 85-92. [CrossRef]

33. Singleton, V.L.; Salgues, M.; Zaya, J.; Trousdale, E. Caftaric acid disappearance and conversion to products of enzymatic oxidation in grape must and wine. Am. J. Enol. Vitic. 1985, 36, 50-56.

34. Zhishen, J.; Mengcheng, T.; Jianming, W. The determination of flavonoid contents in mulberry and their scavenging effects on superoxide radicals. Food Chem. 1999, 64, 555-559. [CrossRef]

35. Wrolstad, R.E.; Skrede, G.; Enersen, G. Influence of sugar anthocyanin pigment stability in frozen strawberry. J. Food Sci. 1990, 55, 1064-1065. [CrossRef]

36. Hamid, S.; Muzaffar, S.; Ahmed, W.I.; Ahmad, M.F.; Munaf, B.M. Physical and cooking characteristics of two cowpea cultivars grown in temperate Indian climate. J. Saudi Soc. Agric. Sci. 2016, 15, 127-134. [CrossRef]

37. Apáez-Barrios, P.; Escalante-Estrada, J.A.; Rodríguez-González, M.T. Crecimiento y rendimiento del frijol chino en función del tipo de espaldera y clima. Trop. Subtrop. Agroecosyst. 2011, 13, 307-315.

38. Guillén-Molina, M.; Márquez-Quiroz, C.; De la Cruz-Lázaro, E.; Velázquez-Martínez, J.R.; Soto-Parra, J.M.; García-Carrillo, M.; Orozco-Vidal, J.A. Biofortificación de frijol caupí (Vigna unguiculata L. Walp) con hierro y zinc. Rev. Mex. Cienc. Agríc. 2016, 17, 3427-3438. [CrossRef]

39. El-Dahshouri, M.F.; El-Fouly, M.M.; Khalifa, R.K.M.; El-Ghany, H.M.A. Effect of zinc foliar application at different physiological growth stages on yield and quality of wheat under sandy soil conditions. Agric. Eng. Int. CIGR J. 2017, 193, 193-200.

40. Nielsen, S.S.; Brandt, W.E.; Singh, B.B. Genetic Variability for nutritional composition and cooking time of improved cowpea lines. Crop Sci. 1993, 33, 469-472. [CrossRef]

41. Sida-Arreola, J.P.; Sánchez, E.; Dávila, Q.G.D.; Zamudio, F.P.B.; Acosta, M.C.H. Can improve iron biofortification antioxidant responde, yield and nutritional in green bean? Agric. Sci. 2015, 6, 1324-1332. [CrossRef]

42. Yashona, D.S.; Mishra, U.S.; Aher, S.B. Response of pulse crops to sole and combined mode of zinc application: A review. J. Soils Crop. 2018, 28, 249-258. 
43. Carvalho, A.F.U.; de Sousa, N.M.; Farias, D.F.; da Rocha-Bezerra, L.C.B.; da Silva, R.M.P.; Viana, M.P.; Gouveia, S.T.; Sampaio, S.S.; de Sousa, M.B.; de Lima, G.P.G.; et al. Nutritional ranking of 30 Brazilian genotypes of cowpeas including determination of antioxidant capacity and vitamins. J. Food Compos. Anal. 2012, 26, 81-88. [CrossRef]

44. Antova, G.A.; Stoilava, T.D.; Ivanova, M.M. Proximate and lipid composition of cowpea (Vigna unguiculata L.) cultivated in Bulgaria. J. Food Compost. Anal. 2014, 33, 146-152. [CrossRef]

45. Baptista, A.; Pinho, O.; Pinto, E.; Casal, S.; MotaI, C.; Ferreira, S.M. Characterization of protein and fat composition of seeds from common beans (Phaseolus vulgaris L.), cowpea (Vigna unguiculata L. Walp) and bambara groundnuts (Vigna subterranea L. Verdc) from Mozambique. Food Meas. 2017, 11, 442-450. [CrossRef]

46. Gutiérrez-Uribe, J.A.; Romo-Lopez, I.; Serna-Saldívar, S.O. Phenolic composition and mammary cancer cell inhibition of extracts of whole cowpeas (Vigna unguiculata) and its anatomical parts. J. Funct. Foods 2011, 3, 290-297. [CrossRef]

47. Jyung, W.H.; Ehmann, A.; Schlender, K.K.; Scala, J. Zinc nutrition and starch metabolism in Phaseolus vulgaris L. Plant Physiol. 1975, 55, 414-420. [CrossRef] [PubMed]

48. Chavan, A.S.; Khafi, M.R.; Raj, A.D.; Parmar, R.M. Effect of potassium and zinc on yield, protein content and uptake of micronutrients on cowpea [Vigna unguiculata (L.) Walp.]. Agric. Sci. Dig. 2012, 32, 175-177.

49. Mengel, K.; Kirkby, E.A.; Kosegarten, H.; Appel, T. Zinc. In Principles of Plant Nutrition; Mengel, K., Kirkby, E.A., Kosegarten, H., Appel, T., Eds.; Springer: Dordrecht, The Netherlands, 2001; pp. 585-597. [CrossRef]

50. Lambot, C. Industrial potential of cowpea. In Challenges and Opportunities for Enhancing Sustainable Cowpea Production; Fatokun, C.A., Tarawali, S.A., Singh, B.B., Kormawa, P.M., Tamò, M., Eds.; International Institute of Tropical Agriculture: Ibadan, Nigeria, 2002; pp. 367-423.

51. Broadley, M.; Brown, P.; Cakmak, I.; Rengel, Z.; Zhao, F. Function of nutrients: Micronutrients. In Marschner's Mineral Nutrition of Higher Plants, 3rd ed.; Marschner, P., Ed.; Academic Press: London, UK, 2012; pp. 191-248. [CrossRef]

52. Timko, M.P.; Singh, B.B. Cowpea, a multifunctional legume. In Genomics of Tropical Crop Plants; Moore, P.H., Ming, R., Eds.; Springer: New York, NY, USA, 2008; Volume 1, pp. 227-258. [CrossRef]

53. Huett, D.O.; Maier, N.A.; Sparrow, L.A.; Piggot, T.J. Vegetable crops. In Plant Analysis: An Interpretation Manual, 2nd ed.; Reuter, D.J., Robinson, J.B., Eds.; CSIRO: Collingwood, Victoria, Australia, 2008; pp. $383-464$.

54. Fageria, N.K.; Baligar, V.C.; Clark, B.C. Micronutrients in crop production. Adv. Agron. 2012, 77, $185-268$.

55. Prasad, R.; Shivay, Y.S.; Kumar, D. Interactions of zinc with other nutrients in soils and plants-A review. Indian J. Fertil. 2016, 12, 16-26. [CrossRef]

56. Hawkesford, M.; Horst, W.; Kichey, T.; Lambers, H.; Schjoerring, J.; Møller, I.S.; White, P. Functions of macronutrients. In Marschner's Mineral Nutrition of Higher Plants, 3rd ed.; Marschner, P., Ed.; Academic Press: London, UK, 2012; pp. 135-189. [CrossRef]

57. Broadley, M.; Brown, P.; Cakmak, I.; Ma, J.F.; Rengel, Z.; Zhao, F. Beneficial elements. In Marschner's Mineral Nutrition of Higher Plants, 3rd ed.; Marschner, P., Ed.; Academic Press: London, UK, 2012; pp. $249-269$. [CrossRef]

58. Márquez-Quiroz, C.; De-la-Cruz-Lázaro, E.; Osorio-Osorio, R.; Sánchez-Chávez, E.; Huijara-Vasconcelos, J.J.; Sida-Arreola, J.P. Contenido de zinc y rendimiento de frijol caupí biofortificados. Rev. Mex. Cienc. Agric. 2018, 20, 4175-4185. [CrossRef]

59. Frota, K.; Soares, R.; Arêas, J. Composição química do feijão caupi (Vigna unguiculata L. Walp), cultivar BRS-Milênio. Ciênc. Tecnol. Aliment. 2008, 28, 470-476. [CrossRef]

60. Cakmak, I. Possible roles of zinc in protecting plant cell from damage by reactive oxygen species. New Phytol. 2000, 146, 185-205. [CrossRef]

61. Andresen, E.; Peiter, E.; Küpper, H. Trace metal metabolism in plants. J. Exp. Bot. 2018, 69, 909-954. [CrossRef]

(C) 2020 by the authors. Licensee MDPI, Basel, Switzerland. This article is an open access article distributed under the terms and conditions of the Creative Commons Attribution (CC BY) license (http://creativecommons.org/licenses/by/4.0/). 